\title{
Recent advances in the development of transgenic papaya technology
}

\author{
Evelyn Mae Tecson Mendoza ${ }^{1, *}$, Antonio C. Laurena ${ }^{1}$ and \\ José Ramón Botella ${ }^{2}$ \\ ${ }^{1}$ Institute of Plant Breeding, Crop Science Cluster, College of Agriculture, \\ University of the Philippines Los Baños, College, Laguna, Philippines \\ ${ }^{2}$ School of Integrative Biology, Faculty of Biological and Chemical Sciences, \\ University of Queensland, Brisbane, Queensland 4072, Australia
}

\begin{abstract}
Papaya with resistance to papaya ringspot virus (PRSV) is the first genetically modified tree and fruit crop and also the first transgenic crop developed by a public institution that has been commercialized. This chapter reviews the different transformation systems used for papaya and recent advances in the use of transgenic technology to introduce important quality and horticultural traits in papaya. These include the development of the following traits in papaya: resistance to PRSV, mites and Phytophthora, delayed ripening trait or long shelf life by inhibiting ethylene production or reducing loss of firmness, and tolerance or resistance to herbicide and aluminum toxicity. The use of papaya to produce vaccine against tuberculosis and cysticercosis, an infectious animal disease, has also been explored. Because of the economic importance of papaya, there are several collaborative and independent efforts to develop PRSV transgenic papaya technology in 14 countries. This chapter further reviews the strategies and constraints in the adoption of the technology and biosafety to the environment and food safety. Constraints to adoption include public perception, strict and expensive regulatory procedures and intellectual property issues.
\end{abstract}

Keywords: papaya, Carica papaya, transgenic, genetically modified, biosafety, PRSV-resistant papaya, long shelf life papaya.

\section{Introduction}

Papaya is an important fruit commodity with total world production of 6.708 million metric tons in 2004, up from 6.415 million metric tons average from 1996 to 1997 [1]. The top ten papaya producers are Brazil, Mexico, Nigeria, Indonesia, India, Ethiopia, Congo, Peru, China and the Philippines. Mexico, Brazil and Belize are the main exporters of papaya to the US market while USA (Hawaii) and the Philippines supply the Japanese market. The major suppliers of papaya to the European Union market are Brazil $(>50 \%)$ and Netherlands (17\%) [2].

Ripe papaya fruits are popularly eaten fresh and can be processed into jam, jelly, marmalade, candy, puree and as a component of tropical fruit cocktails. The green or unripe fruits can be added to viands as vegetable and

*Corresponding author: Tel.: +63-49-576-0025. Fax: +63-49-536-3438.

E-mail: emtmendoza@nast.ph; emtmphil@yahoo.com (E.M. Tecson Mendoza). 
are made into a pickled product called achara. In addition, the latex from green papaya fruits is the source of papain which is used as meat tenderizer, in clarifying beer, in the production of fish concentrates for animal feed and various food processing steps. Papaya is also utilized in the pharmaceutical and cosmetics industries.

The papaya industry is beset by two major problems, disease infestation especially by the papaya ringspot virus (PRSV) which can cause up to $100 \%$ losses and postharvest losses of up to $30 \%-40 \%$. PRSV has caused enormous devastation of papaya farms in various countries worldwide resulting in decline in fruit production. On the other hand, papaya fruits in general have short shelf life, especially in tropical countries. The quality of the fruits suffers during handling, storage, transport, distribution and retail resulting in poor appearance, texture, flavor and overall acceptability.

Breeding for resistant papaya against PRSV has resulted only into tolerant varieties because of the absence of PRSV resistance in the Carica family. Attempts to hybridize wild relatives with Carica papaya had also been unsuccessful due to incompatibility and production of infertile hybrids [3]. It was only recently that the hybridization of $C$. papaya with Vasconcellea quercifolia resulted into fertile resistant hybrids [4].

In the mid-1980s, efforts to develop PRSV-resistant papaya by using genetic engineering by the groups of Dr. Dennis Gonsalves of Cornell University and Dr. Richard Manshardt of the University of Hawaii [5] resulted in the commercialization of two transgenic cultivars, SunUp and Rainbow in 1998 [6]. This collaboration led to the development and commercialization of the first transgenic fruit crop, first transgenic tree and the first from a public institution.

The success in developing PRSV-resistant papaya using transgenic technology and advances made in various aspects of the technology has encouraged other institutions to utilize the technology in addressing other problems of papaya that are not amenable or difficult to address using conventional techniques. These problems include short shelf life and postharvest losses, insect infestation by mites and aphids, susceptibility to root and fruit rot, toxicity to high aluminum in acid soils, etc. Further, the possibility of using papaya for the production of pharmaceuticals has been explored. The importance of papaya to the economies of many countries, especially the developing ones, is evidenced by the wide utilization of the transgenic technology for the improvement of papaya in these countries. In many cases, technology transfer has been facilitated through collaboration and/or networking between and among research institutes.

In 2004, the University of Hawaii Center for Genomics, Proteomics and Bioinformatics Research Initiative (CGPBRI) formed a consortium to sequence the papaya genome for the Hawaii Papaya Genome Project [7]. The knowledge that can be derived from the sequencing of the papaya genome can be utilized in further improving the quality and productivity of 
papaya by molecular or conventional techniques. The consortium includes the Maui High Performance Computing Center, Hawaii Agricultural Research Center (HARC, US Department of Agriculture), the Pacific Telehealth \& Technology Hui and Nankai University, China.

This chapter focuses on recent advances in papaya transgenic technology and includes: (a) transformation systems for papaya, (b) development of economically important traits in papaya by genetic engineering, (c) strategies and constraints in the adoption of the technology and (d) safety aspects. Several review articles have dealt with the transgenic PRSV-resistant papaya [6,8-10] and papaya biotechnology [11].

\section{Transformation systems for papaya}

\section{Promoters}

The only promoter used in the transformation of papaya for various traits is the cauliflower mosaic virus (CaMV) $35 \mathrm{~S}$ promoter (Table 1). This constitutive promoter can drive high levels of transgene expression in both dicots and monocots [12-13]. From the first PRSV-resistant GM papaya developed in the early 1990 s $[5,14]$ up to the present time, the CaMV $35 \mathrm{~S}$ promoter continues to be the most common nonplant-derived promoter in use for transgenic technology for most commercial crops including papaya.

\section{Selection markers}

The availability of selectable markers is an integral part of any plant transformation strategy. The most common selectable marker gene used in the production of transgenic papaya is the neomycin phosphotransferase (nptII) gene that confers kanamycin resistance. This marker has been used by several research groups in the development of PRSV-resistant papaya [15-24], resistance to mites [25] and Phytophthora [26], aluminum and herbicide tolerance [27-28], delayed ripening trait [29] and production of vaccine against cysticercosis [30] and tuberculosis [31] (Table 1).

Other selectable markers used in papaya are herbicide resistance genes, antimetabolite selectable markers and fluorescing protein-encoding genes. The bar gene encodes the enzyme phosphinothricin acetyl transferase (PAT) which can confer resistance to herbicides such as glufosinate or BASTA. Cabrera-Ponce [28] utilized the bar and nptII selectable markers and obtained papaya plants which could withstand up to $3 \% \mathrm{w} / \mathrm{v}$ of phosphinothricin, 3 to 5 times higher than the dose recommended for field application. Souza et al. [32] recovered transgenic papayas using herbicide concentrations in excess of $125 \mu \mathrm{M}$ glufosinate applied to papaya somatic embryos.

The antimetabolite selectable marker gene pmi (phosphomannose isomerase) [33] encodes an enzyme that catalyzes the reversible interconversion of 
Table 1. Transformation systems used in genetic engineering of papaya.

\begin{tabular}{|c|c|c|}
\hline & Trait & References \\
\hline \multicolumn{3}{|l|}{ Promoter } \\
\hline $\begin{array}{l}\text { CaMV35S (Cauliflower mosaic } \\
\text { virus } 35 \mathrm{~S} \text { ) }\end{array}$ & All traits mentioned below & Cited below \\
\hline \multicolumn{3}{|l|}{ Selection markers } \\
\hline nptII (neomycin & PRSV resistance & {$[15-24]$} \\
\hline \multirow{5}{*}{ phosphotransferase II) } & Resistance to mites & \\
\hline & Resistance to Phytophtora & \\
\hline & Herbicide resistance & \\
\hline & Delayed ripening & \\
\hline & $\begin{array}{l}\text { Vaccine against cystercercosis } \\
\text { and tuberculosis }\end{array}$ & {$[30-31]$} \\
\hline \multirow{4}{*}{$\begin{array}{l}\text { bar/PAT (bialaphos resistance/ } \\
\text { phosphinothricin } \\
\text { acetyltransferase) } \\
\text { hph }\end{array}$} & Herbicide resistance & [28] \\
\hline & Vaccine against cystercosis & [30] \\
\hline & Vaccine against tuberculosis & [31] \\
\hline & $\begin{array}{l}\text { Vaccine against cystercosis } \\
\text { and tuberculosis }\end{array}$ & {$[30-31]$} \\
\hline gus (beta-glucuronidase) & Herbicide resistance & [28] \\
\hline Green fluorescent protein (GFP) & Optimization study & [35] \\
\hline pmi (phosphomannose isomerase) & Optimization study & [34] \\
\hline \multicolumn{3}{|l|}{ Delivery } \\
\hline \multirow[t]{2}{*}{ Agrobacterium } & PRSV resistance & {$[17,38-42]$} \\
\hline & Vaccine against tuberculosis & [31] \\
\hline \multirow[t]{6}{*}{ Particle bombardment } & PRSV resistance & {$[14,39,44-47]$} \\
\hline & Resistance to mites & [35] \\
\hline & Resistance to Phytophtora & {$[26]$} \\
\hline & $\begin{array}{l}\text { Aluminum and herbicide } \\
\text { resistance }\end{array}$ & [27-28] \\
\hline & $\begin{array}{l}\text { Long shelf life or delayed } \\
\text { ripening trait }\end{array}$ & {$[29,48-51]$} \\
\hline & Vaccine against cystercercosis & [30] \\
\hline
\end{tabular}

mannose-6-phosphate and fructose-6-phosphate. Plant cells lacking this enzyme are incapable of surviving on synthetic medium containing mannose, and therefore, the gene has been used to select for transformants on media containing the sugar mannose. Papaya embryogenic calli have little or no PMI activity and cannot utilize mannose as a carbon source. Earlier work showed that mannose at concentrations from 0.1 to $120 \mathrm{~g} / \mathrm{L}$ alone or together with sucrose does not affect papaya secondary somatic embryo development [32]. Consequently, Zhu et al. [34] developed a transformation protocol for papaya using pmi as a selectable marker. This marker proved to be more efficient than either antibiotic or a visual marker for selection of transformants. Zhu et al. [35] also developed a transformation protocol using the green fluorescent protein (GFP) gene insert as a selectable marker. 


\section{Delivery systems}

\section{Agrobacterium-mediated transformation}

Agrobacterium tumefaciens is a Gram-negative phytopathogen that causes crown gall disease, manifested as tumors of stem tissues in more than one hundred plant species mostly belonging to the dicot family [36]. The earliest experiments done in papaya involved the Agrobacterium infection of leaf discs and recovery of transgenic callus [37] but there was no regeneration of whole plants. The first transformation of papaya using Agrobacterium was reported by Fitch et al. in 1993 [17]. Since the late 1990s, various research laboratories in different countries have successfully used the Agrobacteriummediated transformation in generating transgenic papaya plants containing either the $c p$ or the replicase viral genes of PRSV [38-42].

\section{Particle bombardment technology}

Fitch et al. [14] described the transient and stable transformation of papaya (C. papaya L.) using various tissues such as immature, zygotic embryos, hypocotyl sections and somatic embryos using the $n p t \mathrm{II}$ and gus A genes as the selectable marker and reporter gene, respectively. The same group in Hawaii [5] demonstrated an efficient gene gun transfer system of a construct containing the nptII, gusA and the PRSV-cp genes to 2,4D-treated immature zygotic embryos. A system for the production of transgenic papayas using zygotic embryos and embryogenic callus as target cells was also reported by Cabrera-Ponce et al. [28] using the bar and nptII genes as selectable markers and the gus A as the reporter gene. Gonsalves et al. [43] used the gene gun in transferring an untranslatable $c p$ gene derived from PRSV HA 5-1 and some of the resulting transgenic lines were resistant to PRSV.

These pioneering studies in the early and late 1990s paved the way for other research groups to use particle bombardment in developing transgenic papaya with novel traits such as virus resistance [39,44-47], delayed ripening $[29,48-51]$ and other useful traits $[25,26,30]$ (Table 1).

\section{Tissue culture system}

The pioneering work on the tissue culture system of Fitch and Manshardt [52] led to the successful transformation and regeneration of papaya transgenic plants. Their system is based on the protocol developed for the generation of embryogenic cultures in walnuts [53] and can be used with either Agrobacterium or biolistic transformation. The original tissue culture protocols have been modified and improved specifically with regard to induction of somatic embryos, transformation efficiency, increased dosage of antibiotic to minimize chimeras and regenerative capacity after transformation $[41,49,54-57]$. 
Under the Australia-Philippines-Malaysia international research collaboration funded by the Australian Centre for International Agricultural Research (ACIAR) and the corresponding country funding agencies, the tissue culture system developed by Fitch and Manshardt [52] was further modified and improved for the three papaya cultivars used in each of the participating countries [50].

\section{Development of economically important traits in papaya by genetic engineering}

\section{Resistance to pests and diseases}

Papaya has several economically important pests and diseases [3]. Among the insect pests, leafhoppers (Empoasca sp.) and mites, including the carmine spider mite (Tetranychus cinnabrinus Boisd.) cause serious damage to papaya plants. Aphids (Aphis sp.), which abound in various host weeds, attack papaya after their host weeds dry up and can transmit PRSV. PRSV, a potyvirus, is the number one viral disease in papaya-growing countries and, thus, is a major limiting factor in papaya cultivation. Papaya seedlings are subject to damping-off diseases caused by Phytophthora, Pythium and Rhizoctonia species. Anthracnose caused by Colletotrichum gloeosporioides infests leaf petioles and fruits. Postharvest diseases include Phytophthora stem-end rot (Phytophthora nicotianae var. parasitica), Phomopsis rot (Phomopsis caricae-papayae), anthracnose (C. gloeosporioides), black stemend rot (Phoma caricae-papayae and Lasiodiplodia theobromae) and Alternaria rot (Alternaria alternata) [58]. A comprehensive listing of the different pests and diseases of papaya is included in the OECD compendium on the biology of papaya [3].

\section{Development of PRSV resistance in papaya}

PRSV is a major viral disease of papaya in Hawaii. It was discovered in 1948 by Jensen in Hawaii [59]. Reports of PRSV infestation of papaya farms were reported in Thailand [60], in Taiwan in 1975 [61] and in the Philippines in 1982 [62]. While PRSV is not a major problem in Australia, it is considered as an important threat to its papaya industry [4]. PRSV-infected papaya plants exhibit chlorotic leaves, ringed spots on the fruit and the upper part of the trunk, distortion of leaves which resembles the damage of mites, and depressed fruit production and eventually the infected plants die.

Control of PRSV includes rouging infected plants and spraying with aphicides. However, rouging cannot stop the spread of the disease once it is established. Similarly, spraying with aphicides is often ineffective since the virus is transmitted to the plants before the aphids are killed [63]. Interplanting rows of non-host crops between papaya rows allows vectors to feed on the non-hosts before they feed on papaya, and thus reduces transmission of disease and incidence [6]. Inoculation of a mild strain of 
PRSV or a mutated virus can result in cross protection; however, the protection was found to be temporary and ineffective perhaps due to the mutability of the virus [64].

Resistance to PRSV in papaya has not been identified in the C. papaya germplasm and thus, no resistant variety of papaya has been developed although PRSV-tolerant varieties have been produced [9,65]. An example of a PRSV-tolerant papaya variety is the Tainung No. 5 which has had poor acceptance due to inferior consumer qualities [66]. The hybrid Sinta papaya developed by Dr. Violeta Villegas in the Philippines also exhibits tolerance to PRSV and can provide a good harvest for the farmer even if infected but will eventually decrease in production because of infection.

Another strategy to control PRSV is the breeding of resistant varieties by interspecific hybridization of C. papaya with Vasconcellea sp. Interspecific hybridization studies, summarized in the consensus document on papaya [3], had limited success due to incompatibility problems and production of infertile hybrids. More recently, Drew et al. [4] reported that their intergeneric crosses between Vasconcellea quercifolia and $C$. papaya have produced fertile hybrids. Moreover, backcrossing has produced several fertile intergeneric hybrids with PRSV resistance.

In the mid-1980s, with the success in the development of genetically modified crops such as maize, cotton and soybean, the complete molecular characterization of PRSV [67] and the difficulty of obtaining resistant varieties of papaya through conventional methods of breeding, scientists from Cornell University and University of Hawaii initiated the development of PRSV-resistant papaya by genetic engineering.

The most common strategy used to protect against PRSV has been to develop transgenic papaya plants expressing the PRSV-cp. These plants exhibit "pathogen-derived resistance" through a process that might be similar to the natural phenomenon of viral cross protection [68-70]. The $c p$ of the PRSV is the dominant viral gene and has been the preferred choice of scientists in 11 countries to develop PRSV-resistant papaya through genetic engineering [11]. The second preferred viral gene encodes the nuclear inclusion protein $\mathrm{b}($ nib) that contains conserved motifs characteristic of RNA-dependent RNA polymerase of positive-strand RNA virus and is adjacent to the $c p$ gene; this has been used by several researchers $[39,40,42,71]$.

The US was the first country to develop genetically engineered PRSVresistant papayas, SunUp and Rainbow. Countries such as Jamaica, Taiwan and Thailand have already completed successful field testing but are still awaiting commercialization, while countries such as Australia, Malaysia, Philippines and Vietnam are still in the field testing stage. The Papaya Biotechnology Network of Southeast Asia facilitated by the International Service for the Acquisition of Agri-biotech Applications (ISAAA) was established in 1998 among national laboratories in Indonesia, Malaysia, 
Philippines, Thailand and Vietnam. One of the major objectives of this international network is to develop PRSV-resistant papaya using modern biotechnological approaches and utilizing the local and preferred varieties of the participating countries [72].

Under this network, control of PRSV using genetic engineering through $\mathrm{CP}$-mediated protection and antisense technology was adopted by participating institutions in different countries. Although the CP-mediated resistance for PRSV in papaya has been successfully developed in Hawaii, an alternative strategy is the antisense technology which confers resistance at the RNA level. In this case, the full-length viral gene of $c p$ or Nib is not required. Vietnam is developing GM papayas for PRSV resistance using both CP-mediated protection and antisense technology [42].

The following discusses the different initiatives in various countries in developing PRSV-resistant papaya through genetic engineering.

\section{In Hawaii}

After the initial success transforming and regenerating transgenic papaya using a gene construct with the gus A reporter gene and the selectable marker $n p t \mathrm{II}$ using particle bombardment technology [14], the next step was transformation with a construct containing the $c p$ gene of a mild crossprotecting strain HA5-1 isolated in Hawaii. Resistant lines were generated $[5,20,73]$ and one of these, $R_{0}$ line 55-1, a red-fleshed Sunset female with a single insert of the $c p$ gene was crossed with a non-transgenic Sunset. $\mathrm{R}_{1}$ progenies positive for the transgene were selfed and advanced until homozygous $\mathrm{R}_{4}$ plants still positive for the transgene were obtained. These advanced materials called SunUp were further crossed with non-transgenic Kapoho and the resulting hybrid was called Rainbow.

Field tests and commercialization. Transgenic PRSV-resistant papayas [5] were field tested on a small-scale in 1992 [20] which was also the year when a severe PRSV virus epidemic devastated the Hawaiian papaya industry. In late 1995, a five-acre demonstration plot of Rainbow and SunUp was planted during a virus epidemic on the island of Puna and these lines showed dramatic resistance over the susceptible commercial cultivars (Fig. 1).

In 1997 the US regulatory agencies approved the commercialization of transgenic papaya after completing their review of the product. Hawaii's Papaya Administrative Committee (PAC) had to obtain license agreements with owners of the patented genetic engineering technology. The negotiated licenses include limitations-of-use and compliance provisions [74]. Growers must follow five provisions to comply with their contracts. These provisions are: (a) The transgenic papaya can be planted in Hawaii only. (b) Only PAC can sell seeds of the transgenic varieties "Rainbow" and "SunUp." (c) Selling of fruits is limited to countries that have accepted genetically engineered papayas as safe for commercialization. (d) Attendance in an educational 
(a)
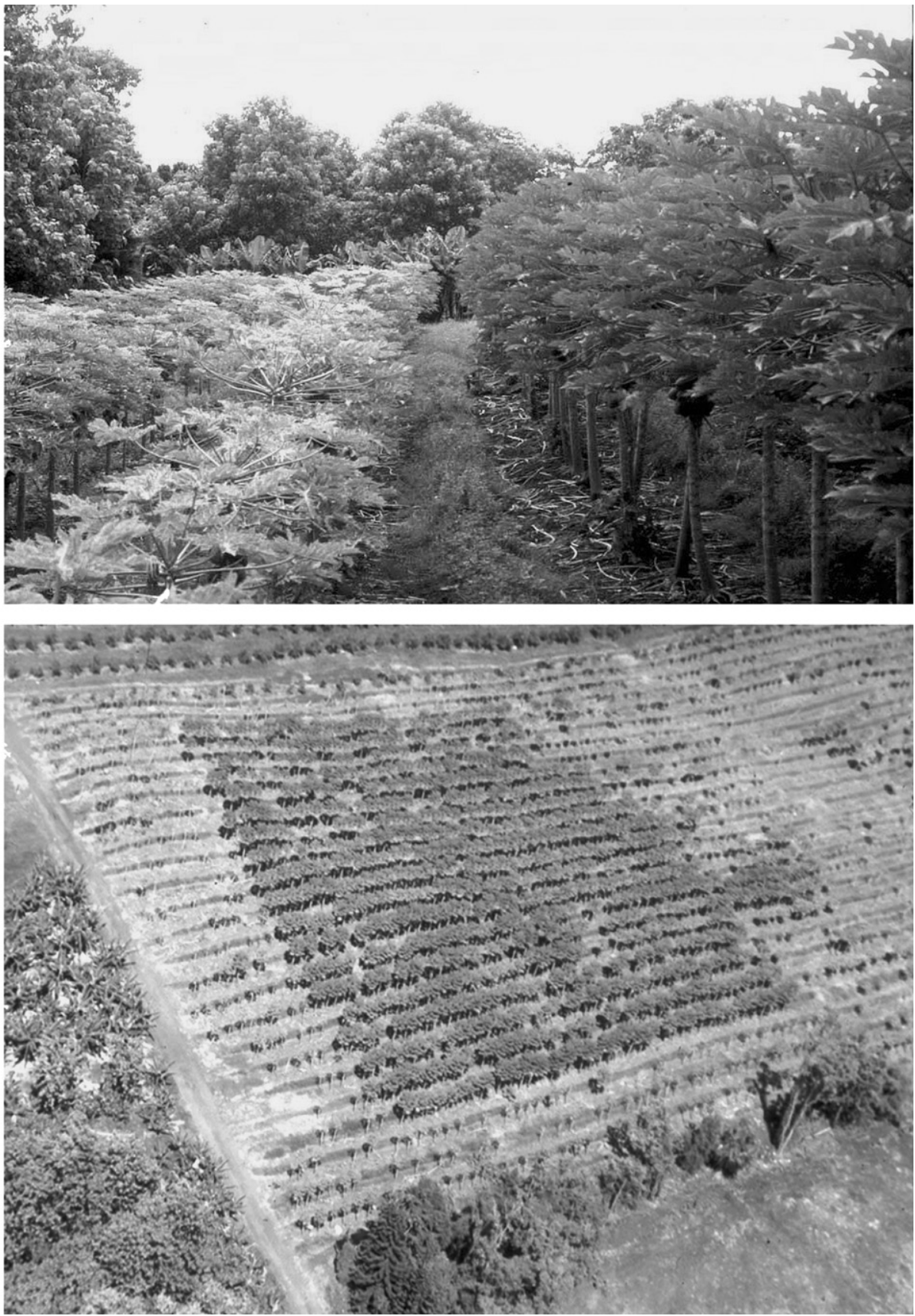

Fig. 1. (a) Non-transgenic papaya plants (left) show effects of PRSV infection vs. transgenic plants (right). (b) Aerial view of the field trial in Puna started in October 1993. Photo shows the healthy transgenic papaya plants surrounded by infected nontransgenic papaya trees (May 1997). (Photos used with permission from Dr. Dennis Gonsalves.) 
session by producers is required. This session covers the requirements of the licenses and PRSV resistance management. (e) Producers are required to sign an agreement to buy seeds only from PAC.

\section{In Brazil}

PRSV is an important problem in Brazil, which is the largest producer of papaya in the world at 1.6 million tons per year, the third largest exporter to the US and the major exporter to Europe.

A technology transfer program to develop PRSV-resistant transgenic papaya for Brazil was formed between the Gonsalves laboratory and Brazilian Agricultural Research Corporation (EMBRAPA) in the early 1990s. The transgenic papaya was developed in the US by visiting Brazilian scientists and then transferred to EMBRAPA. Translatable and nontranslatable $c p$ genes were used as inserts in the transformation of the Sunrise and Sunset Solo varieties using particle gun bombardment on secondary somatic embryos derived from immature zygotic embryos. Fiftyfour transgenic lines were regenerated into whole plants, 26 of them contained the translatable version while 28 had the untranslatable $c p$ gene. Inoculation of the cloned $\mathrm{R}_{0}$ plants with three different virus isolates from Brazil, Hawaii and Thailand revealed some lines with mono-, double- and even triple-resistance under greenhouse conditions [47].

\section{In China}

At least four groups are developing PRSV-resistant transgenic papaya in the People's Republic of China, namely, the Huazhong Agricultural University in Wuhan, Hubei [38], Zhongshan University [75], Sun Yat-sen University and South China Agricultural University, the last three being in Guangzhou. In Huazong Agriculture University, Jiang et al. [38] transformed papaya (cv Sunset) using $A$. tumefaciens strain LBA4404 carrying the binary plasmid pGA482G containing the $c p$ and $n p t$ II genes. The study focused on the development of an effective transformation method by adding a sonication treatment on embryogenic calli; nevertheless regenerated plants with the $c p$ transgene based on PCR and Southern hybridization were obtained. Ye et al. [75] reported the field test of two transgenic papaya $T_{1}$ lines with a replicase mutant gene derived from a strain of PRSV. This study focused on the virus resistance in the field and molecular characterization of the transgenes present in the two lines. The work in South China Agricultural University involved the use of the binary vector $\mathrm{pBI} 121$ without the gus gene containing the replicase gene [76]. The CP gene was also used in the initial work but proved ineffective against the virus.

Commercialization in China. In August 2006, a press release in Beijing announced that the Chinese agriculture authorities granted approval for the commercialization of PRSV-resistant GM papaya to researchers of the 
South China Agricultural University in Guangzhou [76]. Dr. Hauping Li, director of the Plant Virology Laboratory of the same university led the project initiated by his former mentor, Prof. Faan Huaizhong who studied the four strains of PRSV that infected papaya fields in four major southern Chinese provinces. The PRSV disease was first reported in 1959 in Guangdong Province and from there spread to the other papaya-producing provinces. Although there were three varieties of GM papaya developed, only one variety was approved for commercialization, the Huanong No. 1 which is a small "Solo" type papaya similar to the Hawaiian varieties. This variety will be made available to Chinese farmers through a Chinese seed company which will distribute the papaya as micropropagated seedlings to ensure quality and maintain the hermaphrodite character. According to the researchers, no breakdown of resistance occurred in the replicase-silenced GM papaya plants in the past 5 to 6 years. The Chinese researchers estimated that the cost of the papaya project to be about $\$ 250,000$ USD from the beginning in 1990 up to the approval for commercialization in 2006.

\section{In Jamaica}

Transgenic papaya lines containing either of the two inserts, translatable and non-translatable $c p$ genes, were evaluated for field resistance against PRSV [77]. Lines $\left(\mathrm{R}_{0}\right)$ with the translatable $c p$ gene showed $80 \%$ field resistance while lines with the non-translatable $c p$ gene showed only $44 \%$ resistance. The $\mathrm{R}_{1}$ progenies showed similar levels of resistance compared to the parentals. The transgenic lines were found to be gynodioecious with red flesh, weighing between $260 \mathrm{~g}$ and $536 \mathrm{~g}$ and sweetness levels of $11.5-13.5^{\circ}$ Brix. These lines possessed desirable horticultural characteristics and effective viral resistance for the eventual development of a final product with acceptable commercial value.

\section{In Indonesia}

The $c p$ gene was introduced using particle bombardment into two Indonesian varieties of papaya, namely Bangkok and Burung [44]. The construct p2K7/ BICP consisted of the isolated $c p$ gene from a local PRSV strain (Bogor, West Java) under the control of the CaMV 35S promoter. Co-transformation with $\mathrm{p} 2 \mathrm{~K} 7$ vector containing the $c p$ gene and pRQ 6 containing the gus A and hygromycin phosphotransferase $(h p h)$ was done using biolistic delivery.

\section{In Malaysia}

Binary vectors for Agrobacterium-mediated transformation were constructed based on the plant expression vector pMON54904B with two PRSV viral genes, $c p$ and Nib [39]. This Monsanto binary vector (pMON54904B) contained the CaMV $35 \mathrm{~S}$ promoter with a duplicated enhancer region, the hsp17.9 leader sequence derived from soybean and the 35S 3' UTR. The marker gene for selection in this binary vector is the $n p t \mathrm{II}$ for kanamcycin 
resistance. An additional binary vector was made with the $c p$ gene with a $\sim 250 \mathrm{bp}$ inverted repeat of the $c p$ gene inserted downstream of the stop codon. Immature zygotic embryos derived from the variety Eksotika were used in co-cultivation experiments with Agrobacterium using a modified method of Ying et al. [57]. A total of 87 transgenic lines were generated from all constructs and are in various stages of field trials.

\section{In the Philippines}

The first initiative to develop transgenic papaya with PRSV resistance was undertaken at the Institute of Plant Breeding (IPB), the Philippine's national breeding center for all crops (except rice), under the College of Agriculture, University of the Philippines Los Baños. The construct contained the $c p$ gene derived from a PRSV virulent strain isolated in Cavite [45]. A total of 188 targets were derived from 7,845 primary somatic embryos and were bombarded with the pCP-LBP plasmid containing the $c p$ gene using the particle gun. Three months after the bombardment, a total of 48 individual transformation events regenerated into small plantlets. Further, 359 putative transgenic plantlets were produced which were morphologically similar to non-transgenic control plants [46]. All the $\mathrm{R}_{0}$ transgenic lines had moderate to high susceptibility to PRSV. However resistant PRSV $\mathrm{R}_{1}$ lines were derived from $\mathrm{R}_{0}$ lines indicating that the $\mathrm{R}_{0}$ lines were hemizygous for the introduced $c p$ gene and thus selfing was necessary to obtain a full complement of the gene.

Another study was initiated under the ISAAA's Papaya Biotechnology Network of Southeast Asia, which utilized the Agrobacterium-mediated transformation (ABI strain) of papaya somatic embryos [40,78]. Different gene constructs derived from the pMON vector cassettes (pMON 65,306, 65,307 and 65,310) were used containing also different inserts such as the $c p$ (941 bp), Nib (1,574 bp) and a $c p$ inverted repeat fragment ( $250 \mathrm{bp})$. These constructs contain a leader sequence derived from the soybean's $h s p 17.9$ gene to increase translational efficiency of the transgene. The nptII was also incorporated in the pMON vector as the selectable marker. A total of 1,348 somatic embryos were transformed using Agrobacterium and 200 independent transgenic lines were regenerated.

Confined field trial. The Institute of Plant Breeding (IPB) of the University of the Philippines Los Baños is presently conducting confined field trial of candidate lines of GM papaya for PRSV resistance. A confined field trial is an intermediary stage between greenhouse testing and an open field trial. The first two are supervised and regulated by the National Committee on Biosafety of the Philippines (NCBP), while the third is supervised and regulated by the Bureau of Plant Industry (BPI) of the Department of Agriculture (DA). The main objective of this NCBP-regulated confined trial is the disease evaluation screening for resistance to PRSV of three candidate 
$\mathrm{T}_{3}$ lines. A total of 135 inoculated seedlings plus 45 uninoculated and 45 inoculated "Davao Solo" seedlings (control) were planted [79].

\section{In Taiwan}

Embryogenic tissues derived from immature zygotic embryos of the Tainung No. 2 were used for Agrobacterium-mediated transformation using the binary vector pBGCP [41] containing the $c p$ gene of the PRSV YK strain, a severe virus strain from Taiwan [80] and the $n p t$ II selectable marker gene. A total of 38 transgenic lines were tested for PRSV resistance with two lines showing immunity (no symptoms in 4 months), nine highly resistant lines (4-7-week delay in symptom development with attenuation) and eight moderately resistant lines (3-4-week delay in development of severe symptoms) [23].

Field trial. Three transgenic lines were selected for evaluation under field conditions [23]. All three lines were female producing typical fruits not different from the non-transgenic Tainung No. 2 female plants. Fruit yield ranged from 30 to $50 \mathrm{~kg}$ per tree in contrast to $0-20 \mathrm{~kg}$ of the diseased controls. In a first field trial, $0 \%-0.2 \%$ of the three transgenic lines (100 plants each) were infected with PRSV 12 months after planting, while the control plants were $100 \%$ infected 8 months after planting. In a second trial where the transgenic plants were planted adjacent to a diseased orchard, infection rates of $10 \%-20 \%$ were observed 5 months after transplanting. In this trial, the control plants were all infected 3 months after planting. Because infection occurred in the early stage, the control plants did not produce any significant amount of fruits.

\section{In Thailand}

The Thai papaya varieties Khak Dum and Khak Nual were transformed using microprojectile bombardment by Thai scientists at Cornell University (USA) in 1995 [6]. After 2 years, the research team returned to Thailand with two transformed varieties and further conducted breeding and analysis under greenhouse conditions at the research station in Tha Pra, Khon Kaen Province. In selection set 1, three R3 lines (from Khaknuan variety) showed excellent field resistance to PRSV $(97 \%-100 \%)$ and had a yield of fruits 70 times higher than non-transgenic Khaknuan papaya [81]. In selection set 2, one R3 line (Khakdam variety) showed $100 \%$ field resistance.

A small-scale field trial of the $\mathrm{R}_{2}$ transgenic line (KN116/5) for its PRSV resistance and agronomic qualities was conducted from June 2003 to July 2004 in the field testing facility of the Plant Genetic Engineering Unit of BIOTEC, Kasetsart University located in Nakhon Pathom [82]. KN116/5, an advanced transgenic line derived from the Thai papaya variety Khak Nual, was found to be highly resistant $(97 \%)$ to PRSV infection during the oneyear field test while the non-transgenic plants were all infected 2 months after planting. Fruit yield from the transgenic line was approximately 40 times 
higher compared to infected non-transgenic controls. The average fruit weight of transgenic papayas varied from 1.7 to $2.4 \mathrm{~kg} /$ fruit with an average total soluble solids content of $12^{\circ}$ Brix. On the other hand, fruits obtained from non-transgenic papayas were small and blemished with ringspots on the fruit surface.

An independent study was initiated by the National Center for Genetic Engineering and Biotechnology and the Plant Genetic Engineering Unit (PGEU) of Kasetsart University to develop PRSV-resistant transgenic papaya similar to the project initiated in the Gonsalves laboratory. A field trial was also ongoing at Kasetsart University in 2004 when the moratorium on field testing of GE crops forced all such activities to a halt in Thailand.

\section{In Venezuela}

PRSV has always threatened the commercial production of papaya in Venezuela and in 1993, the University of Los Andes linked up with Cornell University for the transfer of the transgenic technology to develop PRSVresistant papaya in Venezuela. In collaboration with Dennis Gonsalves, the first transgenic papaya in this country was developed by the said university using the $c p$ gene from two different geographically isolated PRSV strains isolated from local varieties of papaya grown in the Andean foothills of Merida. After the Agrobacterium-mediated transformation and regeneration of whole plants, four PRSV-resistant $\mathrm{R}_{0}$ plants were intercrossed or selfpollinated and the resulting progenies were found to be resistant against the two different PRSV strains under greenhouse conditions [83].

\section{In Vietnam}

Five papaya varieties (KD Thai, Tim Taiwan, Solo, Mexico and Local Lansom) were chosen as the target for Agrobacterium-mediated transformation using three different plasmid constructs based on pMON65304, pMON65305 and pMON65309, and the A. tumefaciens ABI strain [42]. These constructs contained the $c p$ (in sense and antisense orientation) and $n i b$ genes from a Vietnamese PRSV strain. Twenty-nine transgenic lines were generated using the three different constructs and evaluated under greenhouse conditions.

\section{Developing resistance to mites in papaya}

Mite infestation causes major damage to papaya plantations in Hawaii [84-85]. The transgenic PRSV-resistant cultivar Rainbow is, however, susceptible to both the leafhopper and mites since its female parent, SunUp, and male parent, Kapoho, are very susceptible to the leafhopper and mites, respectively. To enhance papaya resistance to the carmine spider mite, McCafferty et al. [25] transformed a commercial variety of papaya with the gene for chitinase from Manduca sexta ( $m s c h)$. A chitinase gene was previously introduced into tobacco resulting in reduced feeding damage and 
stunted growth of the larvae of the tobacco budworm [86]. Embryogenic calli of papaya were bombarded with the plasmid pBI121 containing the msch gene under the control of CaMV 35S promoter and the nptII gene under the control of the nopaline synthase promoter as selectable marker.

Nineteen independent lines were identified after selection with geneticin (G418) and confirmed to be transgenic by PCR. The presence and expression of the msch gene were likewise confirmed by RT-PCR. Chitinase activity was higher by up to $52 \%$ in the transgenic leaf extracts compared to control. Bioassays performed in the laboratory showed that the plants expressing the msch gene significantly inhibited the multiplication of the mites. Under field conditions, the number of mites on most transformed lines was significantly lower than the control Kapoho. Two lines, T-23 and T-14 had significantly higher mite counts than control. However, by the end of 10 weeks, the control plants died while lines T-23 and T-14 had grown new leaves. These results indicate a greater tolerance of the transgenic lines to the mites.

\section{Developing resistance to phytophthora in papaya}

Papaya is highly susceptible to Phytophthora palmivora at the seedling and mature stages causing fruit and root rot particularly during the rainy season and in poorly drained soil [87]. To improve the resistance of papaya to Phytophthora, Zhu et al. [26] introduced the defensin gene from Dahlia merckii by particle bombardment in embryogenic calli of papaya. The dahlia defensin has been shown to inhibit the in vitro growth of a broad range of fungi [88-89]. The defensin gene has also been introduced in different crops resulting in enhanced resistance to their respective fungal pathogens, e.g., radish defensin in tobacco vs. the leaf pathogen Alternaria longipes [90] and tomato vs. A. solani [91].

The gene construct used by Zhu et al. [26] contained the defensin gene from dahlia driven by CaMV $35 \mathrm{~S}$ promoter and the $n p t \mathrm{II}$ gene under the control of the nopaline synthase (NOS) promoter as selectable marker. Twenty-one geneticin resistant calli were selected from 20 bombarded plate cultures. These putative transformation events were confirmed by PCR using specific primers for the dahlia gene and by an ELISA assay for the NPT II protein. The defensin was estimated to range from $0.07 \%$ to $0.14 \%$ total soluble protein (TSP) in callus and from $0.05 \%$ to $0.08 \%$ TSP in the leaves of young plants. The mycelial growth of $P$. palmivora was inhibited by $35 \%-50 \%$ by leaf extracts of the transgenic lines. Further, inoculation experiments in the greenhouse showed that defensin expressing transgenic papaya plants had increased resistance against $P$. palmivora. The roots of the infected transgenic papaya were $40 \%-50 \%$ heavier than infected control plants. Increased resistance was associated with shorter growth of the hyphae of $P$. palmivora at the infection sites. These results indicate that defensin expression in papaya could be a good strategy to enhance resistance of papaya to $P$. palmivora. 


\section{Development of aluminum and herbicide tolerance in papaya}

Acid soils affect about $40 \%$ of the arable land worldwide. Aluminum (in the form of $\mathrm{Al}^{3+}$ in acid soils) is toxic to most plants. Organic acid excretion by crops is always associated with tolerance to aluminum. Thus, overproduction of an organic acid in a crop either by conventional breeding or through genetic engineering could address this major problem of aluminum toxicity. De la Fuente et al. [27] reported the production of transgenic papayas by particle bombardment with constructs driving the overexpression of the citrate synthase (cs) gene from Pseudomonas aeruginosa. Lines expressing the $c s$ gene accumulated and released two to three times more citrate than control plants. The transgenic lines were able to form roots and grow in solutions containing up to $300 \mu \mathrm{M}$ of aluminum unlike the control plants. Overexpression of $c s$ in tobacco resulted in even more dramatic results, with transgenic plants producing four-to-ten-fold of citrate over control plants. The results of the study demonstrated that excretion of organic acid is a mechanism of aluminum tolerance in plants.

In their efforts to increase the efficiency of particle bombardment transformation methods in papaya, Cabrera-Ponce et al. [28] utilized a construct containing phosphinothricin (bar) and nptII resistance genes, and the gus gene (uidA) under the control of CAMV 35S promoter. The incorporation of the transgenes in the transgenic plants was confirmed using a histological fluorimetric assay for GUS, a NPT assay and Southern analysis. To assess the reaction of the transgenic plants to herbicide, phosphinothricin was applied on leaves of transgenic plants and control. Transgenic plants withstood applications of the herbicide while the control plants were very sensitive and showed total necrosis two weeks after application. The transgenic plants were tolerant to herbicide at concentrations 3 to 5 times higher than recommended for field applications and thus show potential for use in commercial plantations.

\section{Development of long shelf life papaya}

Aside from pest infestation, a major problem of papaya, like other fruits, is postharvest losses which could reach $30 \%-40 \%$ of production. After harvest, undesirable environmental and physical conditions during handling, storage, transport, distribution and retail can dramatically reduce the quality of papaya fruits, resulting in poor appearance and suboptimal texture and flavor. In general, papayas have a short shelf life of 4 to 5 days at room temperature of $25^{\circ} \mathrm{C}-28^{\circ} \mathrm{C}$ and up to 3 weeks at lower temperatures of $10^{\circ} \mathrm{C}-12^{\circ} \mathrm{C}$ [92]. When stored at $15^{\circ} \mathrm{C}$ and $20^{\circ} \mathrm{C}$, the quality and, thus, marketability of papaya fruit are affected primarily by flesh softening and shriveling indicating overripeness [93]. Like other tropical fruits, papaya fruits are sensitive to low temperatures below $10{ }^{\circ} \mathrm{C}$ and may develop 
symptoms of chilling injury such as pitting of the skin, hard lumps around the vascular bundles, scald, water soaking of the flesh and abnormal ripening with uneven coloration and greater susceptibility to diseases [93-95].

Several strategies have been adopted to prolong the shelf life of papaya or delay ripening by genetic engineering: (1) suppressing the production of ethylene by blocking the synthesis of key enzymes such as ACC synthase (ACS) or the ACC oxidase (ACO) and (2) suppressing the synthesis and activity of cell wall degrading enzymes like polygalacturonase (PG).

Climacteric fruits, including papaya, are characterized by an increased respiration rate at an early stage in the ripening process accompanied by autocatalytic ethylene production. In climacteric fruits, ACC synthase and ACC oxidase mRNAs accumulate sequentially with the rise in ethylene evolution [96]. Thus, inhibiting the production in ethylene production by blocking the synthesis of ACC synthase or ACC oxidase have been shown to delay ripening and increase fruit life in other climacteric fruits such as tomato and cantaloupe melons [97-99].

\section{Suppressing ethylene production strategy}

The authors were involved in a tri-country (Australia, Philippines and Malaysia) collaborative project under a grant from the Australian Centre for International Agricultural Research (ACIAR) from 1997 to 2005 [100].

Two different ACS cDNA fragments were isolated from ripe fruits of papaya (variety Solo Kapoho or Philippine Solo) using RT-PCR and degenerate primers designed based on the conserved regions of the ACS protein [29,101]. acsl (Gen Bank Accession number AF 178076) is $1194 \mathrm{bp}$ long and codes for 397 amino acids while the acs2 (AF 178077) is $1192 \mathrm{bp}$ long and codes for 396 amino acids. Northern blot analysis showed that only acs 2 transcript was detectable during ripening of the Solo papaya, with a maximum at $60 \%$ ripe and leveling off at the $100 \%$ ripe stage. However, acs 1 was detectable at the green mature stage. Similar results had been reported earlier by Mason and Botella [101] on the same two ACS genes in papaya var. Australia 2001. However, the ripening-related gene in the Philippine papaya hybrid Sinta was found to be only of the acsl type although at least four isoforms of the transcripts possibly generated by different RNA splicing were detected [102].

Gene constructs were prepared using $p G T V \mathrm{a}$ as the primary vector containing acs 2 in antisense orientation and $p G T V \mathrm{~b}$ as the secondary vector which contains the selectable marker $n p t I I$ expression cassette [29]. Optimum bombardment conditions for transforming somatic embryos of papaya were determined using transient expression of GUS [49]. After bombardment, tissues were allowed first to recover from the bombardment for 1 month after which they were subjected to selection on a medium containing kanamycin [50]. Untransformed tissues stopped growing, became yellow, chalky white or 
bleached and eventually died, while, putatively transformed tissues were yellowish or golden yellow and grew well on kanamycin-containing medium. Putative transgenic tissues were regenerated into plantlets which were hardened in a humidity chamber and transferred to a biosafety level (BL2) screenhouse for growing out and evaluation.

Based on molecular and phenotypic analysis [103], twelve papaya trees were selected. The bases for selection were: (1) molecular (presence of antisense acs2 and nptII selection marker), (2) outstanding fruit qualities including delayed ripening trait, (c) high yield and (d) overall tree stand. Hermaphrodite trees were also preferred over female trees to enable faster attainment of homozygosity and stability of the transgenic trait. In general, the selected trees had a good stand with normal sigmoidal growth and prolific growth habit producing 15-48 fruits upon reaching the first sign of ripening (color break).

Large farms harvest fruits at the green mature stage. However, the "green mature" stage is difficult to assess resulting in a number of prematurely picked fruits that eventually translate in a lack of uniformity in terms of aroma, texture, taste and sweetness. We adopted the practice of small farmers and breeders to harvest fruits at color break (about 10\% yellow) at which point, the fruits are ready to ripen. The fruits of the selected transgenic papaya lines exhibited similar number of days from color break to full color of 6-7 days compared with 5-6 days for control non-transgenic fruits. However, the number of days from full yellow to fully ripe stage was more pronounced and significant: 4-14 days for selected transgenic lines compared with 2 days for control non-transgenic papayas. Evaluation of the fruit was done at ambient room temperature of $28^{\circ} \mathrm{C}-30^{\circ} \mathrm{C}$. This is the first proof of concept that the strategy of controlling the ethylene production at the gene level can delay the ripening of a fruit from a tree [103].

Figure 2 shows fruits of selected transgenic and control at fully ripe stage. The transgenic fruits exhibited $11-14^{\circ}$ Brix total soluble solids similar to control. Among the quality traits determined, softening was most significantly different between the transgenic and non-transgenic fruit. The transgenic papaya fruit stayed firm from 4 to 14 days after reaching full yellow stage at room temperature $\left(28^{\circ} \mathrm{C}-30^{\circ} \mathrm{C}\right)$ while the non-transgenic control fruit lost firmness 1 to 2 days after the full yellow stage. From color break to the $95 \%$ yellow stage, the transgenic and control fruits had similar firmness of $\gg 130 \mathrm{~N}$ and at full yellow stage, they also exhibited similar firmness of $111 \mathrm{~N}$ and $113 \mathrm{~N}$, respectively. However, the non-transgenic control fruit continued to lose firmness while the transgenic fruit exhibited a slower rate (negative hyperbolic curve) of loss of firmness [103]. At 12 days after full yellow, transgenic papaya fruit had firmness of $73 \mathrm{~N}$ compared with control of $12 \mathrm{~N}$. Further biochemical analysis showed substantial equivalence of the transgenic papaya fruits with delayed ripening trait with control fruits 

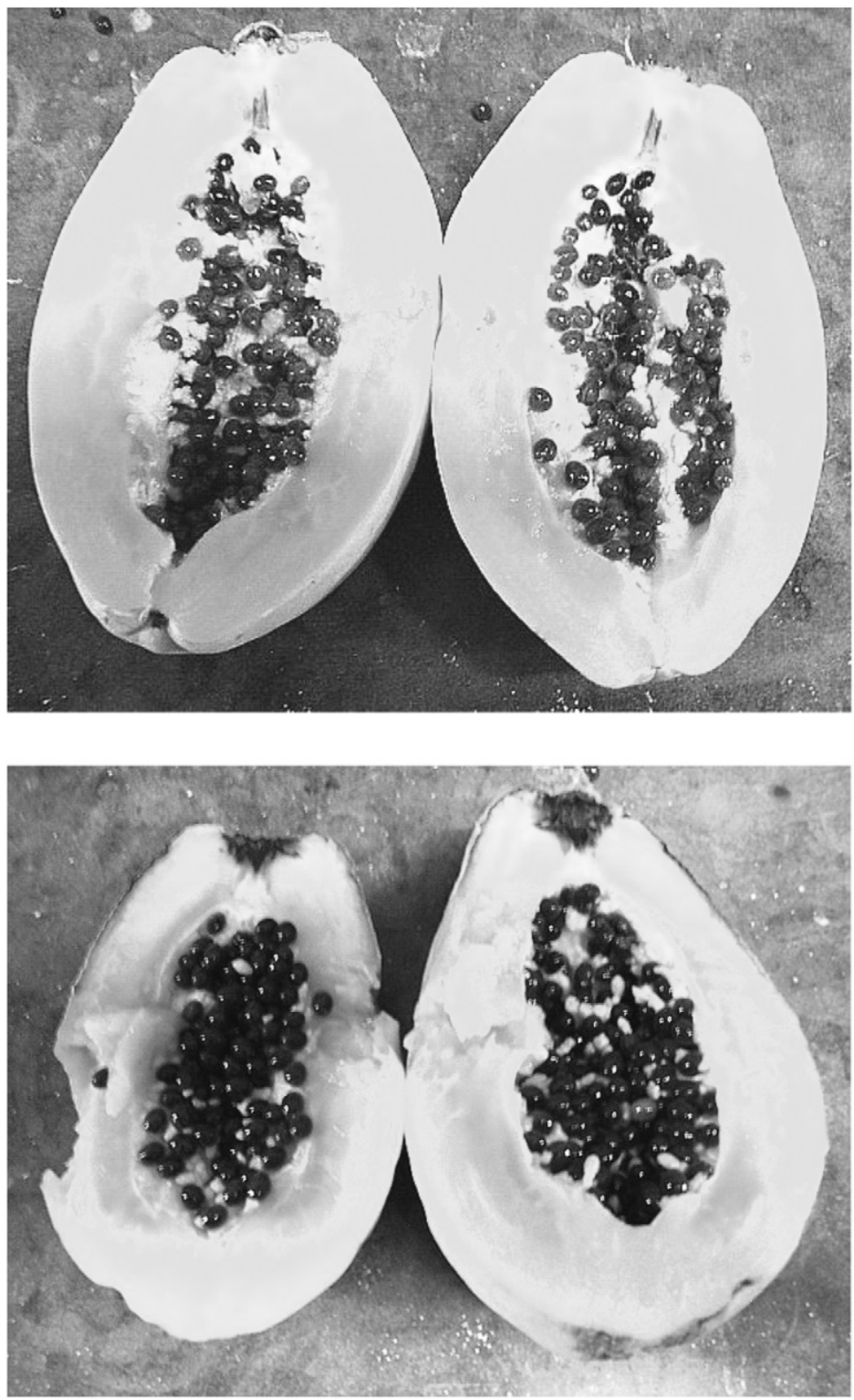

Fig. 2. At a similar stage of 12 days after full yellow, selected transgenic papaya with delayed ripening trait (upper photo) was still firm at $94 \mathrm{~N}$ compared with control papaya (lower photo) which was much softer at 12 N. (From Cabanos et al. [103].) 
in terms of proximate chemical composition, beta-carotene, vitamin $\mathrm{C}$ and benzyl isothiocyanate contents.

On the Australian project side, about 100 transgenic trees were produced and field tested $[48,100]$. The fruits from transgenic trees exhibited increased shelf life of up to two weeks from color break similar to the results obtained by the Filipino team with no change in other characters. This technology was patented by Dr. Jimmy Botella and the University of Queensland (US Patent No. 67124525) covering ACC synthase genes from papaya, pineapple and mango with utility to produce transgenic plants "in which the expression of the ACC synthase is substantially controlled to affect the regulation of plant development, particularly, fruit ripening" [104].

The Malaysian group in MARDI also initiated research on developing papaya var. Eksotika by genetic engineering using antisense ACC oxidase [105] and ACC synthase [106] which they reported to be in contained field evaluation [107-108].

Attempts to develop papaya with delayed ripening trait at the Research Institute for Food Crops Biotechnology in Bogor, Indonesia, were initiated in 2001 using antisense ACC oxidase by particle bombardment of embryogenic calli [44].

Neupane et al. [109] cloned ACC synthase and ACC oxidase cDNAs from partially ripe papaya fruits $(30 \%$ yellow). The cloned cDNAs were used as probes to isolate full-length genes of ACC synthase and ACC oxidase cDNAs from a library made from $30 \%$ yellow papaya fruits. They reported a single ACC synthase gene and a multigene ACC oxidase family and the transformation of papaya with sense and antisense ACC synthase. However, the fruit of the transgenic plants did not exhibit delayed ripening or decreased fruit softening [11].

\section{Reducing softening strategy}

This strategy focuses on modifying the expression of genes involved in delaying the softening of tissues. In 2006, Pais et al. [110] were granted a US patent $(7,084,321$ B2) for their invention "Isolated DNA molecules related to papaya fruit ripening." The patent included the DNA sequences of three genes, pectin methylesterase, $\beta$-galactosidase and polygalacturonase isolated from papaya and methods in promoting or delaying papaya fruit ripening through their effects on tissue softening.

Paull and Jung Chen [111] obtained a patent for the cloning and isolation of xylanase genes which can be utilized to create transgenic plants whose growth, abscission, dehiscence and/or fruit and vegetable ripening characteristics can be controlled.

In Malaysia, attempts to delay the softening of papaya have been undertaken by introducing $\beta$-galactosidase in antisense orientation to reduce the activity of said cell wall degrading enzyme $[106,108]$. 
Fitch [11] mentioned in her review that papaya plants have been transformed with antisense polygalacturonase and endoxylanase and transgenic plants were in greenhouse tests. However, no further publication or announcement has come out regarding these activities. While this strategy, if successful, can inhibit and delay the softening of tissues and thus prolong the firmness of the fruit, all other attributes of ripening will still proceed at normal rates.

However, the strategy aimed at inhibiting ripening-related ethylene production can result in the delay or lowering of ethylene production and in the delay in the formation of the various attributes of ripening. Thus, so far, only the introduction of antisense acs 2 in papaya plants from the work in the authors' laboratories $[48,100,103]$ has produced delayed ripening in papaya and has demonstrated proof of concept. Their work showed that the delay in the ripening was accompanied by prolonged firmness of the tissues and slightly longer time to attain full coloration.

\section{Field testing}

Transgenic papaya trees developed to have fruits with the delayed ripening traits have been field tested in Queensland [48,100] and in the Philippines [112]. In March 2007, after obtaining the permit for field testing the transgenic papaya, 194 seedlings of transgenic papaya representing four events and control papaya were planted in a field in Laguna, Philippines under the supervision of representatives from the Philippine biosafety regulatory bodies. This constituted the first field testing of a homegrown biotech crop in the Philippines. All plants of the three events of advanced generations were positive for antisense acs 2 and negative for the kanamycin resistance gene marker. One line, T0218 was positive for both. The control plants were negative to both genes. By May 2007, several plants started to flower. Infection of plants by papaya ringspot virus was observed. Differential reaction of the trees to PRSV, indicating varying degrees of tolerance, was noted. Fruits were still obtained from the infected transgenic plants and some of the control plants.

To address the PRSV problem, selected lines of the transgenic papaya with delayed ripening trait will be crossed with PRSV-resistant backcross of $C$. papaya $\mathrm{x} V$. quercifolia from the collaborative project of Dr. Rod Drew of Griffiths University and Dr. Simeona V. Siar of the University of the Philippines Los Baños.

\section{Production of pharmaceuticals}

\section{Vaccine against cysticercosis}

The use of transgenic papaya as a new antigen delivery system for the production of a vaccine against cysticercosis has recently been reported by Hernandez et al. [30]. Cysticercosis is an infectious disease that affects 
humans through pigs which serve as host for the parasite Taenia solium. The vaccination of pigs could reduce or eliminate the transmission of this disease to humans. Three peptides, KETc1, KETc12 and KETc7, consisting of 12, 8 and 18 amino acids, respectively, were originally identified in $T$. crassiceps [113-114] and have been shown to have high protective capacity in piglets under endemic field conditions [115-116]. The development of an oral edible vaccine in plants could provide a better delivery system for both pigs and humans since both acquire $T$. solium eggs through ingestion.

Embryogenic papaya cells were co-transformed with the pUI 235-5.1 vector containing either of three inserts for the above-mentioned peptides and the pWRG1515 plasmid containing GUS-A, hph gene (providing hygromycin resistance) or $n p t I I$ gene (providing kanamycin resistance) using particle bombardment [30]. KETc1 and KETc12 were modified to contain additional six histidine residues to increase their size and aid in their identification. Embryogenic transgenic papaya clones were selected using hygromycin and kanamycin. Forty-one transgenic clones were obtained and the presence of the transgenes in the genome confirmed using RT-PCR and real-time PCR. Soluble extracts of the transgenic and control embryogenic calli were used to immunize female mice $(\mathrm{BALB} / \mathrm{cAnN})$. Antibodies induced by the transgenic extracts were histochemically detected in $T$. crassiceps tissues. Subcutaneous immunization with the soluble extracts of transgenic clones provided complete protection in about $90 \%$ of immunized mice. The authors' strategy to propagate and use the calli instead of completely regenerating the tissues to trees is quite innovative. They argued that the cell culture of papaya was low cost and this eliminated the issues surrounding the release of transgenic plants in the environment.

\section{Vaccine against tuberculosis}

An initial study to develop a vaccine against tuberculosis in papaya was done by Zhang et al. [31] by introducing the esat-6 gene from Mycobacterium tuberculosis under the control of the CaMV 35S promoter and using the hph gene as selection marker for Agrobacterium-mediated transformation. Selected transgenic papaya plantlets were shown to have incorporated the gene by PCR and Southern analysis and expression was demonstrated by RNA blot analysis. However, it still needs to be shown if the protein produced by the transgenic plant is immunogenic when injected into test animals.

\section{Safety to the environment and food safety}

Transgenic papayas, like other genetically modified organisms, are subject to biosafety regulations regarding their potential impacts on the environment and on human and animal health. In general, risks to the environment include: (1) possible effects on non-target organisms such as beneficial 
insects, mammals, wildlife, endangered or threatened species and the microbial community, (2) possibility of gene flow, (3) possibility of crossing with wild relatives and thus developing weedy relatives and (4) possible persistence in the environment. Food safety concerns include the possible presence of toxins and/or allergens. More specific concerns will depend on the particular strategy used. For example, a potential safety issue with virusresistant transgenic plants is heteroencapsidation, in addition to those already mentioned. Recently, Fuchs and Gonsalves [10] published a critical review of studies on the safety of virus-resistant transgenic crops which have been commercialized.

\section{Biosafety to the environment}

\section{Heteroencapsidation or transencapsidation}

Heteroencapsidation or transencapsidation may result from any interaction between the coat protein $(\mathrm{CP})$ expressed by the transgene and another virus infecting the same plant which can lead to synergism, recombination and heteroencapsidation. It is theoretically possible that the CP protein produced by transgenic papayas carrying the $c p$ gene may interact with PRSV-W virus strains. PRSV-P and PRSV-W are closely related potyviruses. The former infects both papayas and cucurbits while the latter infects cucurbits but not papayas. In one study, the Thai transgenic papaya NK $116 / 5 \mathrm{R}_{4}$ and $\mathrm{R}_{5}$ lines containing the PRSV-P $c p$ gene were tested for the possibility of infection by a PRSV-W superinfecting strain under screenhouse conditions [117]. No disease symptoms were observed and there was complete absence of PRSV-W using the ELISA tests. Infection occurred after 2 weeks in pumpkins inoculated with PRSV-W as positive controls for the study. The presence of PRSV-W was confirmed in infected tissues using RT-PCR with $N i b$ specific primers. These results showed that transencapsidation in the transgenic papaya $\mathrm{NK} 116 / 5 \mathrm{R}_{4}$ and $\mathrm{R}_{5}$ lines did not occur during artificial PRSV-W inoculation.

Moreover, after more than 10 years of commercialization of the PRSVresistant transgenic papaya, the emergence of virus species with undesirable characteristics has not been reported [10].

\section{Effect on microbial community}

The possible effects of transgenic papaya plants on the microbial community of the rhizosphere have been studied under greenhouse conditions [118]. Transgenic and non-transgenic papayas were grown in large pots $(1 \mathrm{~m}$ in diameter). Soil samples were taken from the rhizosphere level $(15 \mathrm{~cm}$ depth) every 30-day intervals until the plant fruiting stage. Based on the Principal Component Analyses of the types and number of soil bacteria and population profile characterization, there were no distinct differences of 
the microbial community in the soil samples where transgenic and nontransgenic papaya were grown.

Wei et al. [119] conducted environmental studies which compared the soil properties, microbial communities and enzyme activities in the soil where transgenic papaya containing the PRSV replicase $(r p)$ gene and nontransgenic papaya were planted under field conditions. The RP-transgenic papaya and non-transgenic papaya produced different soils in terms of arylsulfatase, polyphenol oxidase, invertase, cellulase and phophodiesterase enzyme activities. According to their study, the three soil enzymes (arylsulfatase, polyphenol oxidase and invertase) appeared to be more sensitive to the transgenic papaya than the others. The authors suggested that transgenic papaya could alter soil chemical properties, enzyme activities and microbial communities.

In another study, Hsieh and Pan [120] studied the possible effects of PRSV-resistant transgenic papaya on soil microorganisms in different layers of soil (down to $15-30 \mathrm{~cm}$ ) collected around the planting area of the papaya. The soil microorganisms in the upper layer and lower layer were $>80 \%$ similar in soils planted with transgenic and non-transgenic plants using various analytical methods such as amplified ribosomal DNA restriction analysis, terminal restriction fragment polymorphism and denaturing gradient gel electrophoresis patterns. The authors concluded that planting PRSV-resistant transgenic plant had only limited effects on the soil microbial community.

Lo et al. [121] used real-time PCR to detect the presence of transgene fragments in the soil samples from an isolated field where transgenic papayas were planted. Three DNA fragments were selected with different molecular sizes, namely 35S-P/PRSV-CP (a 796 bp fragment between 35S CaMV promoter and the CP), pBI121/NOS-T (a $398 \mathrm{bp}$ fragment between the binary vector pBI121 and NOS terminator) and NOS-P/nptII (a $200 \mathrm{bp}$ fragment between the NOS promoter and the $n p t$ II gene). Two DNA fragments, the $796 \mathrm{bp}$ and the $200 \mathrm{bp}$ fragments, were detected at very low levels, less than $30 \mathrm{pg}$ per gram of soil (the detection limit of real-time PCR) while the $398 \mathrm{bp}$ DNA fragment was present at $60 \mathrm{ng}$ per gram of soil. The authors hypothesized that the higher GC content in the $398 \mathrm{bp}$ DNA fragment might be one of the reasons of its greater persistence in the soil. This study also showed that soil DNA extracts did not transform two Acinetobacter spp. due to the very low concentration of transgenic nptII in the extract, indicating the very small possibility or none at all of the occurrence of bacterial transformation.

Only one of the four studies reviewed in this chapter showed some changes in the soil properties and microbial community in soil planted to PRSVresistant transgenic papaya while the three others showed no or limited effects on the microbial community. In a comprehensive assessment of the effects of transgenic crops with 27 different traits on soil microbial 
communities, Widmer [122] noted that many studies showed differences in soil microbiological characteristics between soils planted with transgenic and non-transgenic plants while many other studies showed no effects. Further, Widmer's review [122] revealed that (a) environmental factors had a greater influence on soil microbiological characteristics than the transgenic crops, (b) effects were often restricted to the rhizosphere of the transgenic plant and (c) many of the effects were spatially and temporally limited. Widmer [122] recommended further studies to define which alterations in soil microbial characteristics should be considered as unacceptable damage to a soil system.

\section{Transgene flow}

A major concern especially among organic growers and exporters is the transgene flow through pollination from the transgenic papaya plants to nontransgenic ones. For example, Japan has not approved the sale of transgenic papaya and requires that papaya shipments to Japan do not contain transgenic fruits. To help minimize delay in shipment of papaya to this market, the Hawaii Department of Agriculture adopted an Identity Preservation Protocol (IPP) that growers and shippers need to comply with to receive an IPP certification $[8,123]$. This IPP process has facilitated the papaya shipments to Japan. According to Fuchs and Gonsalves [10], this also suggests that gene flow is quite low among papaya, considering also that most of the papaya plants in Hawaiian commercial plantations are hermaphrodites which are self-pollinated.

According to Manshardt [124], preliminary studies in the island of Puna, Hawaii, showed that transgenic seeds were found in 7\% of non-transgenic hermaphrodites and $43 \%$ of the female plants among the non-transgenic trees that immediately surrounded a large solid block of transgenic papaya plants. However, no transgenic seeds were obtained from PRSV-infected non-transgenic papaya plants $400 \mathrm{~m}$ away from the transgenic crop.

In the Philippines, this is also a concern which is being addressed by researchers undertaking development of GM papaya. Thus, with the long shelf life transgenic papaya, a study on the gene flow from transgenic papaya to control papaya surrounding the transgenic papaya plants is being conducted [112].

\section{Food safety}

Before any transgenic product is commercially released, it has to gain approval for its safety as food and feed to human and animals by the appropriate regulatory body. The FAO-WHO Codex Alimentarius Commission [125] has developed guidelines for the safety assessment of foods derived by modern biotechnology. 


\section{Allergenicity potential}

Viral proteins. For virus-resistant papaya, possible allergenicity could be due to the viral proteins that are expressed in the plants. Using the minimum length of six amino acids recommended by an FAO/WHO Expert Consultation [126] in 2001, the PRSV-CP sequence (EKQKEK), which is present in transgenic SunUp and Rainbow, is identical to a putative allergen determinant (ABA-1) of roundworms [127]. However, Hileman et al. [128] concluded that a threshold of six amino acids will not distinguish allergenic from non-allergenic proteins and will result in a large number of false positives. He instead recommended a minimum threshold of eight amino acids which is consistent with the International Life Science Institute/ Institute of Food Biotechnology Council (ILSI/IFBC) recommendations in 1996 in their decision tree approach which has been adopted internationally by GM food evaluators [129].

Moreover, a report showed that the ABA-1 protein is not an allergen by itself [130] vindicating that the criterion of identical six amino acid stretch may not be sufficient to judge potential allergenicity and, thus, there is a need for additional criteria. It was noted by Fuchs and Gonsalves [10] that virus-infected crops such as papaya, citrus and others have been consumed without any ill effects for many years.

Papain. Papain is a protease which is found mainly in the latex of the unripe papaya fruit but is also present in the leaves and trunk and in the maturing fruit. Evidence shows that papain has caused allergenicity to workers exposed to it causing asthmatic reactions, rhinitis and contact conjunctival irritation [131]. The papain family of thiol proteases is known to immunologically cross react with other thiol proteases such as bromelin from pineapple and ficin from fig.

Based on this review on transgenic papaya technology, the possible problem of papain allergenicity has not been raised in developing transgenic papaya probably because papain is naturally present in papaya, especially in the unripe fruit. However, as a possible unintended effect, researchers may well be advised to monitor the levels of papain in the transgenic papaya at various stages of development and ripening.

\section{Toxicity, unintended effects and substantial equivalence}

Benzyl isothiocyanate (BITC) is considered an antinutrient which has been found to be present in extracts of Cruciferae, Moringaceae, Capparidaceae, Tropaeolaceae, Caricaceae, Gyrostemonaceae and Salvadoraceae [132]. BITC is linked to incidents of spontaneous abortions in pregnant women and with the higher incidence of prostate cancer in Japanese men over the age of 70 [133] as well as to anticancer effects [134].

Results of the BITC assay in PRSV-resistant transgenic papaya [135] using the method of Tang [136] showed that at green mature stage, the total 
potential BITC content in papaya ranged from 7.3 to $32.3 \mathrm{ppm}$ in nontransgenic lines and 11.1-13.2 ppm in transgenic lines. At full yellow stage, total potential BITC level ranged from 1.3 to $3.5 \mathrm{ppm}$ in non-transgenic lines and $1.7-1.8 \mathrm{ppm}$ in transgenic lines. BITC levels in papaya drop 10-100 times from immature to ripe stage and thus BITC does not pose a problem in consuming the ripe fruit. The results also showed that the BITC values of the transgenic compared with the non-transgenic were similar.

In their study of the transgenic papaya with delayed ripening trait, Cabanos et al. [103] observed that the total BITC contents decreased from 14.5 to $11 \mathrm{ppm}$ at green mature stage to $5.5-7.6 \mathrm{ppm}$ at full yellow stage. It was also observed that at mature green stage, the total potential BITC and free BITC had similar values $(10-14 \mathrm{ppm})$ but at full yellow stage, the free BITC values were $0.7-1.5 \mathrm{ppm}$ compared to $5.5-7.6 \mathrm{ppm}$ total potential BITC. The authors noted that the BITC values in transgenic papayas were not significantly different from the control. The values for papaya were also 10-100 times lower than those reported for broccoli, brussels sprouts and cabbage [137]. The results indicate that the BITC in papaya does not pose a threat to human health.

As an index of unintended effects, proximate chemical composition and contents of various nutrients are analyzed in foods derived by modern biotechnology. For the transgenic papaya with delayed ripening trait, contents of moisture, protein, crude fiber, fat, ash and carbohydrate, betacarotene and ascorbic acid were analyzed at three stages of fruit maturity (green mature, 10\% yellow and full yellow) and found to be similar to the values obtained for control papaya and to values in the literature [103]. The results also indicate the substantial equivalence of the transgenic papaya with the control papaya.

\section{Strategies and constraints in the adoption of transgenic papaya technology}

Collaboration and networking characterize the efforts to transfer transgenic papaya technology from the industrial to developing countries. This review revealed that 14 different countries are involved in the development of papaya transgenic technology and they can be grouped into four categories, namely, the Gonsalves-associated group, the ACIAR group with Professor Jimmy Botella of the University of Queensland as Principal Investigator, the ISAAA-led group (Southeast Asia Papaya Biotechnology Network) and the independent groups from research institutions from various countries (Table 2).

In some countries, the same research group formed two collaborations like MARDI of Malaysia which became involved with both the ACIAR- and the ISAAA-led groups. Thailand has two different research groups that are involved in the Gonsalves-associated and the ISAAA-led groups. The Philippines has two different research groups from the same research 
Table 2. Countries involved in developing transgenic papaya technology.

\begin{tabular}{llll}
\hline Gonsalves-associated & ACIAR group & ISAAA-led group & Independent \\
\hline US (Cornell/Hawaii) & Australia & Indonesia & China \\
Brazil & Philippines & Malaysia & Japan \\
Jamaica & Malaysia & Philippines & Mexico \\
Thailand & & Thailand & US (Florida) \\
Venezuela & & Vietnam & US (Virgin Islands) \\
& & & US (Hawaii) \\
\hline
\end{tabular}

institution that are involved in the ACIAR- and the ISAAA-led groups. The US has the most number of research groups (at least four). Various independent research groups were identified in China, Indonesia, Japan, Jamaica, Mexico, Venezuela and Vietnam (Table 3).

There was successful transfer of the transgenic technology in papaya from the Gonsalves research group in Cornell to other countries such as Brazil, Jamaica, Thailand and Venezuela. In Venezuela, the development of transgenic PRSV-resistant papaya and its evaluation under greenhouse testing progressed rapidly but the field testing within the country was stopped early on by pressures from the public who opposed transgenic agricultural products [83]. Similarly, in 2004, the successful field tests of two transgenic papaya lines which showed $97 \%-100 \%$ resistance to the virus were stopped by sustained efforts of Greenpeace and BioThai, a Bangkok-based NGO. In July 2004, Greenpeace trespassed into and held a demonstration in the experimental GM papaya field which was well covered by the local and international presses. Furthermore, Greenpeace claimed that the GM papaya had already escaped into farmers' fields in 37 provinces in Thailand. This incident resulted into the government's investigation which ultimately led to the Thai government's policy of moratorium on all field trials of GM crops. Thus, the future of GM papaya in Thailand was deemed uncertain and would highly depend on a friendly policy on the application of transgenic technology in papaya [76].

While the transfer of transgenic papaya technology could be successfully undertaken through collaboration, networking and sufficient manpower, facilities and funding resources, problems in perception and social acceptability of the technology exist as shown by the experiences in Venezuela and Thailand. However, these problems are not unique to the transgenic papaya as other biotech or genetically modified crops still face consumer resistance, e.g., in the European Union and in Japan. Japan tops the list of countries that have approved the importation of biotech crops for food and feed use and for release into the environment (field tests), although Japan has not approved the importation of papaya [10]. A consumer attitude study in Japan in 2006 showed that $61 \%$ would be reluctant to eat GM food but this is down from the $80 \%$ figure obtained in a similar 
Table 3. Academic research institutions involved in papaya transgenic technology.

\begin{tabular}{|c|c|}
\hline $\begin{array}{l}\text { Grouping/ } \\
\text { country }\end{array}$ & Academic/research institution \\
\hline \multicolumn{2}{|l|}{ Gonsalves group } \\
\hline United States & Cornell University and University of Hawaii \\
\hline Brazil & EMBRAPA \\
\hline Jamaica & University of West Indies, Biotech Centre \\
\hline Thailand & Department of Agriculture \\
\hline \multicolumn{2}{|l|}{$A C I A R$ group } \\
\hline Australia & University of Queensland \\
\hline Philippines & $\begin{array}{l}\text { Institute of Plant Breeding, Crop Science Cluster, College of } \\
\text { Agriculture (CA) University of the Philippines Los Baños } \\
\text { (UPLB) }\end{array}$ \\
\hline Malaysia & $\begin{array}{l}\text { Malaysia Agricultural Research and Development Institute } \\
\text { (MARDI) }\end{array}$ \\
\hline \multicolumn{2}{|r|}{ (m) } \\
\hline Indonesia & $\begin{array}{l}\text { Indonesian Research Institute for Agricultural Biotechnology and } \\
\text { Genetic Resources (IABIOGRI), Agency for Agricultural } \\
\text { Research and Development (AARD) }\end{array}$ \\
\hline Malaysia & MARDI \\
\hline Philippines & Institute of Plant Breeding CA UPLB \\
\hline Thailand & $\begin{array}{l}\text { National Center for Genetic Engineering and Biotechnology } \\
\text { (BIOTEC) Kasetsart University }\end{array}$ \\
\hline Vietnam & $\begin{array}{l}\text { Institute of Biotechnology (IBT), National Centre for Natural } \\
\text { Science and Technology }\end{array}$ \\
\hline \multicolumn{2}{|c|}{ Independent groups } \\
\hline \multirow[t]{3}{*}{ China } & Huazhong Agricultural University (Hubei) \\
\hline & Zhongshan University \\
\hline & South China Agricultural University (Guangzhou) \\
\hline \multirow[t]{3}{*}{ Japan } & $\begin{array}{l}\text { Japan International Research Center for Agricultural Sciences } \\
\text { (Okinawa) }\end{array}$ \\
\hline & $\begin{array}{l}\text { National Agricultural Research Center for Hokkaido Region } \\
\text { (Sapporo) }\end{array}$ \\
\hline & $\begin{array}{l}\text { Department of Agro-bioscience, Faculty of Agriculture, Iwate } \\
\text { University }\end{array}$ \\
\hline Mexico & CINVESTAD, Irapuato \\
\hline \multirow[t]{3}{*}{ USA } & University of Florida \\
\hline & University of Hawaii \\
\hline & University of Virgin Islands \\
\hline
\end{tabular}

poll conducted in 2003 [138]. Another study concluded that a transformation in the consumer perceptions and attitude in Japan is needed before GM food can be successfully accepted by the Japanese consumer [139]. However, the adoption of biotech crops by about 55 million farmers worldwide has reached 114.3 million ha in 2007 in 23 countries, consisting of 
12 developing and 11 industrial countries, and involving 12 crops including papaya [140].

A second source of limitation and/or constraint is the protection of intellectual property rights (IPR) of most biotechnologies. However, the IPRs of most of these biotechnologies are not protected in developing countries, since their owners only sought protection in selected countries usually in the industrial countries. Thus, developing countries can legally access such biotechnologies. However, they may not be technically capable to do so. In such cases, collaboration and networking with more advanced countries has helped in this regard. While patents are territorial, licenses and other contracts such as material transfer agreements (MTAs) are not territorial and will bind institutions in countries even where a technology which is the subject of the MTA or contract is not patented.

A third source of constraint is the strict regulation of products of modern biotechnology. The regulatory system for modern biotech products should now be revised considering the accumulated experiences, lessons and scientific evidence from more than 20 years of field releases of GM crops and regulation and 18 years of commercialization. The overly strict regulation impacts not only on financial resources but also prolongs the time of development of any biotech crop. These should be considered in the revision of the biosafety regulatory system without losing its responsible and rigorous nature.

\section{Concluding remarks}

Very promising advances have been reported in the improvement of papaya using genetic engineering techniques. Important problems such as disease resistance and fruit quality have been targeted and the results have been positive. Promising initiatives in the production of pharmaceuticals in papaya have been reported.

Nevertheless a number of factors are delaying the widespread adoption of the technology. The most important one is the very stringent regulations that affect all transgenic crops, requiring exhaustive environmental and health tests that make it impossible or very difficult for small companies or government institutes to develop and commercialize their own varieties. Public perception is another issue that needs to be carefully considered although the success of the other big GM crops such as soybean, maize, cotton and canola is paving the way for the smaller commodities such as papaya. Finally, intellectual property issues (such as patents and plant variety rights) could further hinder the commercialization of new transgenic papaya varieties, although the fact that papaya is predominantly grown in developing countries could be an advantage since big corporations do not normally pursue patenting in those countries. 


\section{Acknowledgements}

The authors gratefully acknowledge the support from their respective institutions (University of the Philippines Los Baños and University of Queensland), funding agencies (Australian Centre for International Agricultural Research, the Philippine Department of Science and Technology, Philippine Council for Advanced Science and Technology Research and Development, Philippine Council for Agriculture, Forestry and Natural Resources Research and Development, US Agency for International DevelopmentEMERGE and the Department of Agriculture Biotech PIU) and co-workers, staff and students who have participated in the various aspects of our research. Special thanks to Mr. Cerrone S. Cabanos for his help in sourcing many of the articles used in this chapter. We also sincerely thank Dr. Dennis Gonsalves for his kind permission to use two photographs in this chapter.

\section{References}

1. FAO. FAOSTAT database, 2005. Available at http://www.fao.org.

2. Eurostat. Statistics Yearbook. Papaya 2005 and 2006 intra and extra community imports by EU-25, Supplement July-August 2007.

3. OECD. Consensus document on the biology of papaya (Carica papaya), Paris, Organisation for Economic Co-operation and Development, 2005. Available at http:// www.oecd.org/ehs/.

4. Drew RA, Siar SV, O'Brien CM, Magdalita PM and Sajise AGC. Breeding papaya ringspot virus resistance in Carica papaya via hybridisation with Vasconcellea quercifolia. Australian J Exp Agr 2006;46:413-418.

5. Fitch MM, Manshardt RN and Gonsalves D. Virus resistant papaya plants derived from tissues bombarded with the coat protein gene of papaya ringspot virus. Bio/Technol 1992;10:1466-1472.

6. Gonsalves D. Control of papaya ringspot virus in papaya: a case study. Annual Rev Phytopathol 1998;36:415-437.

7. Hawaii Papaya Genome Project. Available at http://cgpbr.hawaii.edu/papaya/.

8. Gonsalves D. Transgenic papaya: development, release, impact, and challenges. Adv Virus Res 2006;67:317-354.

9. Gonsalves D, Vegas A, Prasartsee Vm Drew R, Suzuki J, et al. Developing papaya to control papaya ringspot virus by transgenic resistance, intergeneric hybridization and tolerance breeding. Plant Breed Rev 2006;26:35-78.

10. Fuchs $M$ and Gonsalves D. Safety of virus-resistant transgenic plants two decades after their introduction: lessons from realistic field risk assessment studies. Annu Rev Phytopathol 2007;45:173-202.

11. Fitch MM. Carica papaya. Papaya. In: Biotechnology of Fruit and Nuts Crops, Litz RE (ed), CABI Publishing, 2005, pp. 174-207.

12. Battraw MJ and Hall TC. Histochemical analysis of CaMV $35 \mathrm{~S}$ promoter- $\beta-$ glucuronidase gene expression in transgenic rice plants. Plant Mol Biol 1990;15: $527-538$ 
13. Benfey PN, Takatsuji H, Ren L, Shah D and Chua NH. Sequence requirements of the 5-enolpyruvylshikimate-3-phosphate synthase 5'-upstream region for tissue-specific expression in flowers and seedlings. Plant Cell 1990;2:849-856.

14. Fitch MM, Manshardt R and Gonsalves D. Stable transformation of papaya via microprojectile bombardment. Plant Cell Reps 1990;9:189-194.

15. Chen G, Ye CM, Huang JC, Yu M and Li BJ. Cloning of the papaya ringspot virus (PRSV) replicase gene and generation of PRSV-resistant papayas through the introduction of the PRSV replicase gene. Plant Cell Reps 2001;20:272-277.

16. Davis MJ and Ying Z. Development of transgenic ringspot resistant papaya for Florida. Phytopathol 2002;(Suppl.)518 (Abstract).

17. Fitch MMM, Manshardt RM, Gonsalves D and Slightom JL. Transgenic papaya plants from agrobacterium-mediated transformation of somatic embryos. Plant Cell Reps $1993 ; 12: 245-249$.

18. Mahon RE, Bateson MF, Chamberlain DA, Higgins CM, Drew RA and Dale JL. Transformation of an Australian variety of Carica papaya using microprojectile bombardment. Aust J Plant Physiol 1996;23:679-685.

19. Lines RE, Persley D, Dale JL, Drew R and Bateson M.F. Genetically engineered immunity to papaya ringspot virus potyvirus in Australian papaya cultivars. Mol Breed 2002;10:119-129.

20. Lius S, Manshardt RM, Fitch MM, Slighthom JL, Sanford JC and Gonsalves D. Pathogen-derived resistance provides papaya with effective protection against papaya ringspot virus. Mol Breed 1997;3:161-168.

21. Souza MT and Gonsalves D. Genetic engineering resistance to plant virus diseases: an effort to control papaya ringspot potyvirus in Brazil. Fitopatol Bras 1999;24:485-502.

22. Tennant PF, Ahmad MH and Gonsalves D. Transformation of Carica papaya L. with virus coat protein genes for studies on resistance to papaya ringspot virus from Jamaica. Trop Agric (Trinidad) 2002;79:105-113.

23. Yeh SD, Bau HJ, Cheng YH, Yu TA and Yang JS. Greenhouse and field evaluations of coat-protein transgenic papaya resistant to papaya ringspot virus. Proceedings of International Symposium on Biotechnology of Tropical and Subtropical Species (RA Drew, ed), Brisbane, Queensland, Australia, Acta Hort 1998;461:321-328.

24. Zimmerman TW and St Brice N. Selection of transgenic papaya seedlings using kanamycin and DMSO. In Vitro Cell Dev Biol 2003;39:47-A (Abstract).

25. McCafferty HRK, Moore PH and Zhu JY. Improved Carica papaya tolerance to carmine spider mite by the expression of Manduca sexta chitinase transgene. Transgenic Res 2006;15:337-347.

26. Zhu YJ, Agbayani R and Moore PH. Ectopic expression of Dahlia merckii defensin DmAMP1 improves papaya resistance to Phytophthora palmivora by reducing pathogen vigor. Planta 2007;226:87-97.

27. De la Fuente JM, Ramirez-Rodriguez V, Cabrera-Ponce JL and Herrera-Estrella L. Aluminum tolerance in transgenic plants by alteration of citrate synthesis. Science 1997;276:1566-1568.

28. Cabrera-Ponce JL, Vegas-Garcia A and Herrera-Estrella L. Herbicide resistant transgenic papaya plants produced by an efficient particle bombardment transformation method. Plant Cell Reps 1995;15:1-7.

29. Laurena AC, Magdalita PM, Hidalgo MSP, Villegas VN, Mendoza EMT and Botella JR. Cloning and molecular characterization of ripening-related ACC synthase from papaya fruit (Carica papaya L.). Proceedings of International Symposium on Tropical and Subtropical Fruits (R Drew, ed), Acta Hort 2002;575:163-169. 
30. Hernandez M, Cabrera-Ponce JL, Fragoso G, Lopez-Casillas F, Guevara-Garcia A, Rosas G, Leon-Ramırez C, Juarez P, Sanchez-Garcia G, Cervantes J, Acero G, Toledo A, Cruz C, Bojalil R, Herrera-Estrella L and Sciutto E. A new highly effective anticysticercosis vaccine expressed in transgenic papaya. Vaccine 2007;25:4252-4260.

31. Zhang G-L, Zhou Z, Guo A-P, Shen W-T and Li X-Y. An initial study of transgenic Carica papaya used as a kind of vaccine for anti-tuberculosis. Acta Botanica Yunnanica 2003;2:223-229.

32. Souza MT, Venturoli MF, Coelho MC and Rech-Filho EL. Analysis of marker gene/ selective agent of transgenic papaya (Carica papaya L.) somatic embryos. Braz J Plant Physiol 2001;13:366-373 (Abstract).

33. Joersbo M, Donaldson I, Kreiburg J, Petersen SG, Brunstedt J and Okkels FT. Analysis of mannose selection used for transformation of sugarbeet. Mol Breed 1998;4:111-117.

34. Zhu YJ, Agbayani R, McCafferty H, Albert HH and Moore PH. Effective selection of transgenic papaya plants with the PMI/Man selection system. Plant Cell Rep 2005; 24:426-432.

35. Zhu YJ, Agbayani R and Moore PH. Green fluorescent protein as the sole selectable marker facilitates genetic transformation of papaya, Carica papaya L. Seventh International Congress of Plant Molecular Biology, Barcelona, Spain 2003;S26-S63, p. 388 (Abstract).

36. Agrios G. Plant Pathology, 2nd ed., New York, Academic Press, 1978.

37. Pang SZ and Sanford JC. Agrobacterium-mediated gene transfer in papaya. J Amer Soc Horti Sci 1988;113:287-291.

38. Jiang L, Maoka T, Komori S, Fukamachi H, Kato H and Ogawa K. An efficient method for sonification assisted Agrobacterium-mediated transformation of coat protein (CP) coding genes into papaya (Carica papaya L.). Plant Cell Reps 2005;24:426-432.

39. Pillai V, Daud HM, Flasinski S, Kaniewski WK, Ang OC and Kwok CY. Status of PRSV resistant papaya research in MARDI Malaysia. ISAAA Papaya Biotechnology Network of Southeast Asia, Hanoi, Vietnam, 22-26 October 2001.

40. Aquino MV, Flasinski S, Perez P and Pillai V. Agrobacterium-mediated transformation of Philippine papaya: progress report. ISAAA Papaya Biotechnology Network of Southeast Asia, Hanoi, Vietnam, 22-26 October 2001.

41. Cheng YH, Yang JS and Yeh SD. Efficient transformation of papaya by coat protein gene of papaya ringspot virus mediated by Agrobacterium following liquid phase wounding of embryo genetic tissues with carborundum. Plant Cell Rep 1996;16:127-132.

42. Nhan LD, Lien LQ, Son LV, Linh TM, Hoang NH, Phong DT and Binh LT. Progress report on transformation of $\mathrm{CP}, \mathrm{Nib}, \mathrm{CP}$ antisense and ACC oxidase antisense genes into papaya. Technical Workshop and Coordination Meeting. Papaya Biotechnology Network of Southeast Asia. Hanoi, Vietnam, 22-26 November 2001.

43. Gonsalves C, Cai W, Tennant P and Gonsalves D. Effective development of papaya ringspot virus resistant papaya with untranslatable coat protein gene using a modified microprojectile transformation method. Proceedingss of International Symposium on Biotechnology of Tropical and Subtropical Species (RA Drew, ed), Acta Hort 1998;461:311-319.

44. Damayanti D, Ambarwati, Utami TIR, Mariska I, Hutami S, Purnamaningsih R and Herman M. Transformation study of Carica papaya L. using CO-PRSV and antisense ACC oxidase genes via particle bombardment. UK Papaya Biotechnology Network Meeting, Vietnam, 22-26 October 2001.

45. Villegas VN, Magdalita PM, Valencia LD and Ocampo TD. Development of transgenic papaya resistance to ringspot virus. Country progress report at the Papaya Biotechnology Network of Southeast Asia held in Hanoi, Vietnam, 22-23 October 2001. 
46. Magdalita PM, Valencia LD, Ocampo ATID, Tabay RT and Villegas VN. Towards development of PRSV resistant papaya by genetic engineering. In: New Directions for a Diverse Planet, Proceedings of the 4th International Crop Science Congress, Brisbane, Australia, 26 September-October 2004.

47. Souza MT, Nickel O and Gonsalves D. Development of virus resistant transgenic papayas expressing the coat protein gene from a Brazilian isolate of papaya ringspot virus. Fitopatol Bras 2005;30:357-365.

48. Botella JR, Tecson-Mendoza, Leeton P, Sargent H, Laurena AC, Siar SV, Sajise AG, Garcia RN, Cabanos CS, Angeles JGC, Perez BMY and Magdalita PM. Using genetic engineering to extend the life of papaya fruits. First International Symposium on Papaya, Malaysia, 22-24 November 2005, p. 53 (Abstract).

49. Magdalita PM, Laurena AC, Yabut-Perez BM, Tecson Mendoza EM and Botella JR. Progress in the development of transgenic papaya: transformation of Solo papaya using ACC synthase antisense construct. Proceedings of International Symposium on Tropical and Subtropical Fruits (R Drew, ed), Acta Hort 2002;575:171-176.

50. Magdalita PM, Laurena AC, Yabut-Perez BM, Zaporteza MM, Tecson-Mendoza EM, Villegas VN and Botella JR. Towards transformation, regeneration and screening of papaya containing antisense ACC synthase gene. In: Plant Biotechnology 2002 and Beyond, Vasil IK (ed), Netherlands, Kluwer Academic Publishers, 2003, pp. 323-327.

51. Pillai V, Zulkifli L, Awang K, and Abu Bakar UK. Transformation of Eksotika papaya with an antisense of the ACC oxidase gene. Asia Pacific Conference on Plant Tissue Culture Agribiotechnol, Singapore, 19-23 November 2000.

52. Fitch MM and Manshardt R. Somatic embryogenesis and plant regeneration from immature zygotic embryos of papaya (Carica papaya L.). Plant Cell Reps 1990;9:320 324.

53. McGranaham GH, Leslie CA, Uratsu SL, Martin LA and Dandekar AM. Agrobacterium-mediated transformation of walnut somatic embryos and regeneration of transgenic plants. Biotechnology 1998;6:800-804.

54. Cai W, Gonsalves C, Tennant P, Fermin G, Souza M, Sarindu N, Jan F, Zhu H and Gonsalves D. A protocol for efficient transformation and regeneration of Carica papaya L. In Vitro Cell Dev Biol Plant 1999;35:61-69.

55. Fitch MM, Pang SZ, Slightom JL, Lius S, Tennant P, Manshardt RM and Gonsalves D. Genetic transformation in Carica papaya L. In: Biotechnology in Agriculture and Forestry, Bajaj YPS (ed), Plant Protoplasts and Genetic Engineering V. Berlin, SpringerVerlag, 1994, Vol. 29, pp. 236-256.

56. Litz RE and Conover RA. In vitro somatic embryogenesis and plant regeneration from Carica papaya L. ovular callus. Plant Sci Lett 1982;26:153-158.

57. Ying Z, Yu X and Davis MJ. A new method for obtaining transgenic papaya plants by Agrobacterium-mediated transformation of somatic embryos. Proc Fla State Hort 1999;112:201-205.

58. Kader AA. Produce Facts. Papaya: Recommendations for maintaining postharvest quality. Postharvest Technology Research and Information Centre, Department of Pomology, University of California Davis, 2000. Available at http://rics.ucdavis.edu/ postharvest2/Produce/ProduceFacts/Fruit/papaya.shtml.

59. Jensen DD. Papaya virus diseases with special reference to papaya ringspot. Phytopathology 1949;39:191-211.

60. Prasartsee V, Fungkiatpaiboon A Chompunutrarapa K. Preliminary studies of papaya ringspot virus in the Northeast. NE Regional Office of Agriculture Newsletter, Khon Kaen, Thailand, 1981;10:17-33 (in Thai). 
61. Wang HL, Wang CC, Chiu RJ and Sun MH. Preliminary study on papaya ringspot virus in Taiwan. Plant Prot Bull 1978;20:133-140.

62. Opina OS. Studies on a new virus disease of papaya in the Philippines. Food Fert Technol Cent Bull 1986;33, Taiwan ROC.

63. Pernezny K and Litz RE. Some common diseases of papaya in Florida. Florida Cooperative Extension Service. Plant Pathol Fact Sheet 1999;35pp.

64. Lin CC, Su HJ and Wang DN. The control of papaya ringspot virus in Taiwan, ROC. FFTC Tech Bull 1989;114:1-3.

65. Cook AA and Zettler FW. Susceptibility of papaya cultivars to papaya ringspot and papaya mosaic virus. Plant Disease Rep 1970;54:893-895.

66. Japan International Research Centre for Agricultural Sciences. Papaya ringspot virus (PRSV) and papaya leaf distortion mosaic virus (PLDMV), 2003. Available at http:// www.jircas.affrc.go.jp/kankoubutsu/jarq/33-1/kiritani/kiritani2.html\#table1.

67. Yeh SD, Jan FJ, Chiang CH, Doong TJ, Chen MC, Chung PH and Bau HJ. Complete nucleotide-sequence and genetic organization of papaya ringspot virus-RNA. J Gen Virol 1992;73:2531-2541.

68. Wang HL, Yeh SD, Chiu RJ and Gonsalves D. Effectiveness of cross protection by mild mutants of papaya ringspot virus for control of ringspot disease of papaya in Taiwan. Plant Dis 1987;71:491-497.

69. Yeh SD and Gonsalves D. Evaluation of induced mutants of papaya ringspot virus for control by cross protection. Phytopathol 1984;74:1086-1091.

70. Yeh SD, Gonsalves D, Wang HL, Namba R and Chui RJ. Control of papaya ringspot virus by cross protection. Plant Dis 1988;22:375-380.

71. Jia Hepeng. GM papaya hints at changing attitudes. Biodiversity clearing-house mechanism of China, 2007. Available at http://english.biodiv.gov.cn/zyxw/20073/ t20070302_101264.htm.

72. Hautea RA. The Papaya Biotechnology Network of Southeast Asia. 1st International Symposium on Papaya, Genting Highlands, Malaysia, 22-24 November 2005, p. 54 (Abstract).

73. Tennant PF, Gonsalves C, Ling KS, Fitch M, Manshardt R, Slightom JL and Gonsalves D. Different protection against papaya ringspot virus isolates in coat protein gene transgenic papaya and classically cross-protected papaya. Phytopathol 1994;84: 1359-1366.

74. Nishina MS, Ferreira SJ, Manshardt RM, Cavaletto CG, Llantero E, Mochida L and Perry D. Production requirements of the transgenic papayas 'UH Rainbow' and 'UH SunUp'. Cooperative Extension Service, College of Tropical Agriculture and Human Resources, University of Hawaii at Manoa, 1998, 4pp.

75. Ye CM, Wei XD, Chen DH, Lan CY and Zhu LM. Analyses of virus resistance and transgenes for transgenic papaya. Yi Chuan 2003;25:181-184 (Abstract in English).

76. Davidson SN. The genetically modified (GM) PRSV-resistant papaya in Thailand: a case study for the agricultural biotechnology development in the GMS subregion, New Zealand, Agrifood Consulting International Inc., (AGRICO), USA and ANZDEC Limited, 2006, 25pp.

77. Tennant P, Ahmad MH and Gonsalves D. Field resistance of coat protein transgenic papaya to papaya ringspot virus in Jamaica. Plant Dis 2005;80:841-847.

78. Flasinski S, Aquino VM, Hautea RA, Kaniewski WK, Lam ND, Ong CA, Pillai V and Romyanon K. Value of engineered virus resistance in crop plants and technology cooperation with developing countries. In: Economic and Social Issues in Agriculture 
Biotechnology, Evenson RE, Santaniello V and Zilberman D (eds), CAB International, 2002, pp. 251-268.

79. Lawas TP and Magdalita P. Biotech papaya resistant to PRSV now under confined trials. ABSPII Newslett 2007;3(2):1.

80. Wang $\mathrm{CH}, \mathrm{Bau} \mathrm{HJ}$ and Yeh SD. Comparison of the nuclear inclusion B protein and coat protein genes of five papaya ringspot virus strains distinct in geographic origin and pathogenecity. Phytopathol 1994;84:1205-1210.

81. Sakuanrungsirikul S, Sarindu N, Prasartsee V, Chaikiatiyos S, Siriyan R, Sriwatanakul M, Lekananon P, Kitprasert C, Boonsong P, Kosiyachinda P, Fermin G and Gonsalves D. Update on the development of virus-resistant papaya: virus-resistant transgenic papaya for people in rural communities of Thailand. Food Nutr Bull 2005;26:422-426.

82. Phironrit N, Chowpongpang S, Warin N, Bhunchoth A and Attathom S. Small scale field testing of PRSV resistance in transgenic papaya line KN116/5. First International Symposium Papaya. Genting Highlands, Malaysia, 22-24 November 2005, p. 42 (Abstract).

83. Fermin G, Inglesses V, Garbozo C, Rangel S, Dagert M and Gonsalves D. Engineered resistance against PRSV in Venezuelan transgenic papayas. Plant Dis 2004;88:516-522.

84. LaPlante AA and Sherman M. Carmine spider mite. Cooperative Extension Service, College of Tropical Agriculture, Insect Pest Series No. 3, 1976.

85. Hill DS. Tetranychus cinnabarinus (Boisd.). In: Agricultural Insect Pests of the Tropics and Their Control, Garget J (ed), 2nd ed., Cambridge University Press, 1983, pp. 501-502.

86. Ding X, Gopalakrishnan G, Johnson LB, White FF, Wang X, et al. Insect resistance of transgenic tobacco expressing an insect chitinase gene. Transgenic Res 1998;7:77-84.

87. Nishijima W. Papaya. In: Compendium of Tropical Fruit Disease, Ploetz RC, Zentmyer GA, Nishijima WT, Rohrbach KG and Ohr HD (eds), St. Paul, MN, American Phytopath Soc. Press, 1994, pp. 54-70.

88. Osborn RW, De Samblanx GW, Thevissen K, Goderis I, Torrekens S, Van Leuven F, Attenborough S, Rees SB and Broekaert WF. Isolation and characterisation of plant defensins from seeds of Asteraceae, Fabaceae, Hippocastanaceae ands Saxifragaceae. FEBS Lett 1995;368:257-262.

89. Thevissen K, Ghazi A, De Samblanx GW, Brownlee C, Osborn RW and Broekaert WF. Fungal membrane responses induced by plant defensins and thionins. J Biol Chem 1996;271:15018-15025.

90. Terras FR, Eggermont K, Kovaleva V, Raikhel NV, Osborn RW, Kester A, Rees SB, Torrekens S, Van Leuven F, Vanderleyden J, et al. Small cysteine-rich antifungal proteins from radish: their role in host defense. Plant Cell 1995;7:573-588.

91. Parashina EV, Serdobinskii LA, Kalle EG, Lavorova NV, Avetisov VA, Lunin VG and Naroditskii BS. Genetic engineering of oilseed rape and tomato plants expressing a radish defensin gene. Russ J Plant Physiol 2000;47:417-423.

92. Paull RE, Nishijima W, Marcelino R and Cavaletto C. Postharvest handling and losses during marketing of papaya (Carica papaya L.). Postharvest Biol Technol 1997;11: $165-179$.

93. Proulx E, Nunes MCN, Emond JP and Brecht JK. Quality attributes limiting papaya postharvest life at chilling and non-chilling temperatures. Proc Fla State Hort Soc 2005;118:389-395.

94. Chen NM and Paull RE. Development and prevention of chilling injury in papaya fruit. J Amer Soc Hort Sci 1986;111:639-643. 
95. Thomson AK and Lee GR. Factors affecting the storage behaviour of papaya. J Hort Sci 1971;46:511-516.

96. Lincoln JE, Campbell AD, Oetiker J, Rottmann WH, Oeller PW, Shen NF and Theologis A. Le-Acs4, a fruit ripening and wound-induced 1-aminocyclopropane-1carboxylate synthase gene of tomato (Lycopersicon esculentum): expression in Escherichia coli, structural characterization, expression characteristics, and phylogenetic analysis. J Biol Chem 1976;268:19422-19430.

97. Oeller PW, Min-Wong L, Taylor LP, Pike DA and Theologis A. Reversible inhibition of tomato fruit senescence by antisense RNA. Science 1991;254:437-439.

98. Hamilton AJ, Lycett GW and Grierson D. Antisense gene that inhibits synthesis of the hormone ethylene in transgenic plants. Nature 1990;346:284-287.

99. Ayub R, Guis M, Amor MB, Gillot L, Roustan JP, Latche A, Bouzayen M and Pech JC. Expression of ACC oxidase antisense gene inhibits ripening of cantaloupe melon fruits. Nat Biotechnol 1996;14:862-866.

100. Botella JR. Control of ripening in papaya and mango by genetic engineering. Project Summary. ACIAR, 2006. Available at http://www.aciar.gov.au/printable/project/PHT/ 1994/045.

101. Mason MG and Botella JR. Identification and characterisation of two 1-aminocyclopropane- 1-carboxylate (ACC) synthase cDNAs expressed during papaya (Carica papaya) fruit ripening. Austr J Plant Physiol 1997;24:239-244.

102. Hidalgo MSP, Tecson-Mendoza EM, Laurena AC and Botella JR. Hybrid 'Sinta' papaya exhibits unique ACC synthase I cDNA isoforms. J Biochem Mol Biol 2005; 38:320-327.

103. Cabanos CS, Sajise AG, Siar SV, Laurena AC, Magdalita PM, Garcia RN, Yabut-Perez B, Angeles, JGC, Zaporteza MM, Laureles LR, Villegas VN, Botella JR and TecsonMendoza EM. Transgenic Papaya with Delayed Ripening Trait: Selection and Characterization, submitted for publication.

104. Botella JR. ACC synthase genes from pineapple, papaya and mango. US Patent No. 6,124,525 issued on 26 September 2000. Assigned to the University of Queensland (Queensland $\mathrm{Au}$ ).

105. Abu Bakar UK, Pillai V, Muda P, Fatt LP, Kwok CY and Daud HM. Molecular and biochemical characterisations of Eksotika papaya plants transformed with antisense ACC oxidase gene. Papaya Biotechnology Network of SEAsia: Technical Workshop and Coordination Meeting, Vietnam 22-26 October 2001.

106. Daud HM, Abu Bakar, Pillai V, Lam PF, Hashim H, Tan CS, Sekeli R, Seq YS, Muda P, Raveendranathan P, Chan YK and Ong CA. Improvement of Eksotika papaya through transgenic technology - Malaysia's experience. First International Symposium on Papaya, Malaysia, 22-24 November 2005, p. 49 (Abstract).

107. Muda P, Ravindranathan P, Kwok CY, Abu Bakar UK, Pillai V, Fatt LP, Daud HM. Contained field evaluation of delayed ripening transgenic Eksotika papaya. Paper presented at the Papaya Biotechnology Network of SEAsia Coordination meeting, Bangkok, Thailand, 13 December 2003.

108. Abu Bakar UK, Pillai V, Hashim M and Daud HM. Sharing Malaysian experience with the development of biotechnology-derived food crops. Food Nutr Bull 2005;26(4):432-435.

109. Neupane KR, Mukatira UT, Kato C and Stiles JJ. Cloning and characterization of fruitexpressed ACC synthase and ACC oxidase from papaya (Carica papaya L.). International Symposium on Biotechnology of Tropical and subtropical Species, Brisbane, Australia, 29 September-3 October 1997, Acta Hort 1998;461:329-337. 
110. Pais MSS, Gonzalves D and Balde A. Isolated DNA molecules related to papaya fruit ripening. Patent assigned to Cornell Research Foundation Inc. (NY, USA) and Institute of Applied Science and Technology (Lisbon, Portugal). US Patent 7,084,321 B2, 2006.

111. Paull RE and Jung CN. Plant xylanases. Patent assigned to the University of Hawaii (Hawaii, USA). US Patent 6495743 issued on 17 December 2002.

112. Tecson-Mendoza EMT, Siar SV, Garcia RN, Laurena ACL, Arrienda FQ, Pagulayan S III and Laureles L. Field Testing of Transgenic Papaya with Delayed Ripening Trait Towards Commercialization. Final Report submitted to EMERGE (Grant 06-008), June 2007.

113. Toledo A, Larralde C, Fragoso G, Gevorkian G, Manoutcharian K, Hernandez M, Acero G, Rosas G, Lopez-Casillas F, Garfias CK, Vazquez R, Terrazas I and Sciutto E. Towards a Taenia solium cysticercosis vaccine: an epitope shared by Taenia crassiceps and Taenia solium protects mice against experimental cysticercosis. Infect Immun 1999; 67:2522-2530.

114. Toledo A, Fragoso G, Rosas G, Hernandez M, Gevorkian G, Lopez-Casillas F, Hernandez B, Acero G, Huerta M, Larralde C and Sciutto E. Two epitopes shared by Taenia crassiceps and Taenia solium confer protection against murine T. crassiceps cysticercosis along with a prominent $\mathrm{T} 1$ response. Infect Immun 2001;69:1766-1773.

115. Huerta $M$, de Aluja AS, Fragoso G, Toledo A, Villalobos N, Hernandez $M$, Gevorkian G, Acero G, Díaz A, Alvarez I, Avila R, Beltrán C, Garcia G, Martinez JJ, Sarralde C and Sciutto E. Synthetic peptides vaccine against Taenia solium pig cysticercosis: successful vaccination in a controlled field trial in rural Mexico. Vaccine 2001;20:262-266.

116. Sciutto E, Morales J, Martínez JJ, Toledo A, Villalobos N, Cruz-Revilla C, Meneses G, Hernández M, Díaz A, Rodarte LF, Acero G, Gevorkian G, Manoutcharian K, Paniagua J, Fragoso G, Fleury A, Larralde R, De Aluja AS and Larralde C. Further evaluation of the synthetic peptide vaccine S3Pvac against Taenia solium cysticercosis in pigs in an endemic town of Mexico. Parasitol 2006;4:1-5.

117. Warin N, Phironrit N, Bhunchoth A, Burns P, Chanprame S and Kositratana W. Determination of transencapsidation effects in genetically modified papaya containing the coat protein gene of PRSV-P Superinfected with PRSV-W. Proceedings of 6th Asian Crop Science Association Conference, Bangkok, Thailand, 5-9 November 2007, p. 125 (Abstract).

118. Phironrit N, Phuangrat B, Burns P and Kositratana W. 2007. Determination of possible impact on the cultivation of PRSV resistant transgenic papaya to rhizosphere bacteria using the community-level physiological profiles (CLPP). Proceedings of the Sixth Asian Crop Science Association Conference, Bangkok, Thailand, 5-9 November 2007, p. 126 (Abstract).

119. Wei XD, Zou HL, Chu LM, Liao B, Ye CM and Lan CY. Field released transgenic papaya effect on soil microbial communities and enzyme activities. J Environ Sci (China) 2006;18:734-740 (Abstract).

120. Hsieh Y-T and Pan T-M. Influence of planting papaya ringspot virus resistant transgenic papaya on soil microbial biodiversity. J Agric Food Chem 2006;54:130-137.

121. Lo CC, Chen SC and Yang JZ. Use of real-time polymerase chain reaction (PCR) and transformation assay to monitor the persistence and bioavailability of transgenic genes released from genetically modified papaya expressing nptII and PRSV genes in the soil. J Agric Food Chem 2007;55:7534-7540. 
122. Widmer F. Assessing effects of transgenic crops on soil microbial communities. Adv Biochem Engin/Biotechnol 2007;107:207-234.

123. Camp SG III. Identity preservation protocol for non-GMO papayas. Proceedings of Virus Resistant Transgenic Papaya in Hawaii: A case for technology transfer to lesser developed countries. OECD/USAID/ARS Conference, Hilo, HI, 20-21 October 2003, pp. $95-100$.

124. Manshardt R. Is organic papaya production in Hawaii threatened by crosspollination with genetically engineered varieties. Univ Hawaii Coll Trop Agric Hum. Res Biol-1 2002;3:2pp.

125. FAO/WHO Codex Alimentarius Commission. Principles for Risk Analysis and Guidelines for Safety Assessment of Foods derived from Modern Biotechnology. Adopted at the 26th Session of the Codex Alimentarius. FAO/WHO Food Standards Programme.,2003. Available at http://www.fao.org/ag/agn/agns/biotechnology_codex_en.asp.

126. FAO/WHO Joint FAO/WHO Expert Consultation on Foods Derived from Biotechnology - Allergenicity of Genetically Modified Foods, Rome, 22-25 January 2001. Rome, Food and Agriculture Organisation of the United Nations.

127. Kleter GA and Peijnenburg AACM. Screening of transgenic proteins expressed in transgenic food crops for the presence of short amino acid sequences identical to potential, IgE-binding linear epitopes of allergens. BMC Struct Biol 2002;2:8. Available at http://www.biomedcentral.com/1472-6807/2/8.

128. Hileman RE, Silanovich A, Goodman RE, Rice EA, Holleschak G, Astwood JD and Hefle SL. Bioinformatic methods for allergenicity assessment using a comprehensive allergen database. Int Arch Allergy Immunol 2002;128:280-291.

129. Metcalfe DD, Astwood JD, Townsend R, Sampson HA, Taylor SL and Fuchs RL. Assessment of the allergenic potential of foods derived from genetically engineered crop plants. Crit Rev Food Sci Nutr 1996;36:S165-S186.

130. Paterson JCM, Garside P, Kennedy MW and Lawrence CE. Modulation of a heterologous immune response by the products of Ascaris suum. Infect Immun 2002;70:6058-6067.

131. Steinman H. Papain. Allergens within occupational allergens. Available at http:// www.immunocapinvitrosight.com/dia_templates/ImmunoCAP/Allergen__28129.aspx\#, accessed February 2008.

132. Ettlinger MG and Kjaer A. Sulfur compounds in plants. Rec Adv Phytochem 1968;1: 49-144.

133. Le Marchand L, Hankin JH, Kolonel LN and Wilkens LR. Vegetable and fruit consumption in relation to prostate cancer risk in Hawaii: a reevaluation of the effect of dietary beta-carotene. Am J Epidemiol 1991;133:215-219.

134. Hecht SS, Kenney PM, Wang M and Upadhyaya P. Benzyl isothiocyanate: an effective inhibitor of polycyclic aromatic hydrocarbon tumorigenesis in $\mathrm{A} / \mathrm{J}$ mouse lung. Cancer Lett 2002;187(1-2):87-94.

135. Gonsalves D and Manshardt R. Petition for FDA clearance of papaya ringspot virusresistant transgenic lines 55-1 and 63-1. St. John Plant Science Laboratory, Department of Horticulture, College of Tropical Agriculture and Human Resources, University of Hawaii at Manoa, Hawaii, 1997.

136. Tang CS. Benyl isothiocyanate of papaya fruit. Phytochem 1971;10:117-121.

137. Joseffson E. Distribution of thioglucosides in different parts of Brassica plants. Phytochem 1967;6:1617-1627.

138. Fitzpatrick M. Japan's GM dilemma, 2 October 2006. Available at http://www.just-food. com/article.aspx? ID $=96184$. 
139. McCluskey JJ, Grimsrud KM, Ouchi H and Wahl TI. Consumer Response to Genetically Modified Food Products in Japan Agricultural and Resource Economics Review, October 2003. Available at http://findarticles.com/p/articles/mi_qa4046/is_200310/ai_n9305606.

140. James C. Global Status of Commercialized Biotech/GM Crops: 2007. ISAAA Brief No. 37. ISAAA, Ithaca, NY, 2007. Available at http://www.isaaa.org. 